Columbia Law School

Scholarship Archive

1994

\title{
Unburdening the Undue Burden Standard: Orienting Casey in Constitutional Jurisprudence
}

\author{
Gillian E. Metzger \\ Columbia Law School, gmetzg1@law.columbia.edu
}

Follow this and additional works at: https://scholarship.law.columbia.edu/faculty_scholarship

Part of the Constitutional Law Commons, Law and Gender Commons, and the Sexuality and the Law Commons

\section{Recommended Citation}

Gillian E. Metzger, Unburdening the Undue Burden Standard: Orienting Casey in Constitutional Jurisprudence, 94 CoLUM. L. REV. 2025 (1994).

Available at: https://scholarship.law.columbia.edu/faculty_scholarship/143

This Article is brought to you for free and open access by the Faculty Publications at Scholarship Archive. It has been accepted for inclusion in Faculty Scholarship by an authorized administrator of Scholarship Archive. For more information, please contact scholarshiparchive@law.columbia.edu. 


\title{
UNBURDENING THE UNDUE BURDEN STANDARD: ORIENTING CASEY IN CONSTITUTIONAL JURISPRUDENCE
}

\author{
Gillian E. Metzger
}

\section{INTRODUCTION}

"Liberty finds no refuge in a jurisprudence of doubt." 1 With these words in the 1992 case, Planned Parenthood v. Casey, the Supreme Court ushered in a new era of abortion regulation. ${ }^{2}$ Speaking through a joint opinion authored by Justices O'Connor, Kennedy, and Souter, the Court indicated that from this point forth abortion regulations would be judged by an "undue burden" standard. According to this standard, an abortion regulation is unconstitutional if it "has the purpose or effect of placing a substantial obstacle in the path of a woman seeking an abortion" of a nonviable fetus. ${ }^{3}$

The Justices who wrote Casey were explicit in their desire to resolve the judicial debate over constitutional protection of abortion. This debate had become increasingly contentious in recent years as several Justices forcefully expressed their willingness to overturn the 1973 Roe $v$. Wade ${ }^{4}$ decision constitutionalizing abortion. Casey, however, may have the opposite effect. The joint opinion made clear that the Constitution does protect a woman's right to choose abortion prior to viability of the fetus. But the extent of this protection was left in doubt as a result of the Court's failure to provide methods for determining when an undue burden on abortion exists.

This Note attempts to rectify this deficiency in the Casey undue burden standard by developing a new undue burden methodology based on the analytical approaches used in other areas of constitutional jurisprudence. Three approaches-the two-tiered inquiry of the dormant Commerce Clause, ${ }^{5}$ the content-neutral, traditional forum analysis of the First Amendment, ${ }^{6}$ and the endorsement test of the Establishment Clause ${ }^{7}$ are especially similar to the undue burden standard outlined in Casey and can provide methods for evaluating the purpose and effect of abortion regulations.

In developing a new undue burden methodology, this Note for the most part works within the framework of the undue burden standard as

1. Planned Parenthood v. Casey, 112 S. Ct. 2791, 2803 (1992) (majority opinion).

2. In this Note the term "regulation" is used broadly to refer to any restriction on access to abortion, including restrictions that are found in statutes. This broad definition conforms to the Court's terminology in Casey. See id. at 2820 (joint opinion).

3. Id.

4. 410 U.S. 113 (1973).

5. U.S. Const. art. I, \& 8, cl. 3.

6. U.S. Const. amend. I, cl. 2.

7. U.S. Const. amend. I, cl. 1. 
enunciated in Casey. The joint opinion authors clearly stated that the undue burden standard represented "a standard of general application to which we intend to adhere." ${ }^{8}$ Hence, a new undue burden methodology must be compatible with the joint opinion's account of the undue burden standard if it is to have practical utility. This Note distinguishes, however, between the theoretical framework of the undue burden standard and the joint opinion's application of the standard to the Pennsylvania regulations at issue in Casey. Although the methods extrapolated from other constitutional approaches accord with the former, they often conflict with the latter. Such a distinction is justified by Casey's failure to explain how the undue burden standard should be applied and the inconsistencies in its review of the Pennsylvania regulations.

At the same time, this Note also seeks to underscore the weakness of the standard in the form specified by the joint opinion. The comparison to other constitutional analyses demonstrates that the abortion undue burden standard is virtually unique in its lack of protection against unnecessary and unjustified burdens on a constitutionally protected right. To some extent, developing a new undue burden methodology based on the techniques used in other areas of constitutional jurisprudence can serve to enhance the level of protection offered by the undue burden standard. But in order to provide significant protection against unnecessary or unjustified burdens it is necessary to reconfigure the theoretical framework of the Casey undue burden standard. Although this Note focuses primarily on developing a new methodology that is consistent with the existing form of the undue burden standard, it also suggests one means of reconfiguring the undue burden standard so as to increase the protection of a woman's right to choose abortion.

Part I discusses the current undue burden standard and explains why it is necessary to develop a more concrete methodology for applying the standard. Part I also justifies the approach of developing such a method by drawing on other areas of Constitutional jurisprudence. Part II examines the two-tiered analysis used under the dormant Commerce Clause, compares this analysis to the undue burden standard, and suggests how certain methods used in dormant Commerce Clause analysis could be applied to the context of abortion. Part III examines the analysis applied to content-neutral regulations of speech in traditional forums and the endorsement test of the Establishment Clause, again compares these approaches to the undue burden standard, and extrapolates methods for applying the undue burden standard. Part IV applies these suggested methods to the restrictions at issue in Casey to demonstrate the potential protection that could be secured through a more rigorous undue burden inquiry. Part IV also explores one means of altering the framework of the undue burden standard so as to increase its protection of the right to choose abortion.

8. Planned Parenthood v. Casey, 112 S. Ct. 2791, 2820 (1992) (joint opinion). 


\section{The Undue Burden Standard}

The Casey undue burden standard marked a substantial change in the Supreme Court's approach to abortion. Previously, the Court had examined abortion regulations using the trimester framework developed in Roe. Although the trimester framework had been attacked in decisions which shortly preceded Casey, the Justices had not yet developed a replacement approach. Casey introduced an undue burden standard that demands inquiry into the purpose and effect of abortion regulations. However, the joint opinion's failure to provide a systematic methodology by which to apply the standard undermines the standard's force. This failure may lead to expanded judicial discretion as well as regional variance in women's access to abortion, and thereby deprive some women of their constitutional rights. An examination of the analytic approaches used in three other areas of constitutional jurisprudence-the two-tiered inquiry of the dormant Commerce Clause, the content-neutral, traditional forum analysis applied to regulations on expression, and the endorsement test of the Establishment Clause-suggests methods for applying the undue burden standard.

\section{A. Pre-Casey Abortion Doctrine: Roe and Its Progeny}

Constitutional protection for a woman's right to choose to have an abortion began with the 1973 decision in Roe v. Wade. In the years preceding Roe the Court had determined that the Constitution provides a fundamental right to privacy and decisional autonomy which prevents the government from intruding into certain areas of individuals' lives, such as their choices regarding contraception. ${ }^{9}$ In Roe the Court held that " $[t]$ his right of privacy ... is broad enough to encompass a woman's decision whether or not to terminate her pregnancy." ${ }^{10}$ Yet the Court also argued that the abortion context was different from other areas of decisional autonomy because important state interests were involved, namely concern for the health of the woman and for potential human life. The Court adopted the trimester approach as the means of balancing the woman's privacy right and the state's interests. During the first trimester of pregnancy, neither state interest was deemed strong enough to justify state interference with the woman's decision. Increased medical risks allowed state regulation of abortion during the second trimester, but only if the regulation was aimed at protecting maternal health. At the end of the second trimester, when the fetus became capable of surviving outside of the womb, the state's interest in potential life became compelling. Therefore, at this point the state could proscribe abortion, provided it

9. See Griswold v. Connecticut, 381 U.S. 479 (1965) (holding that a married couple's use of contraception is protected by the right to privacy); Eisenstadt v. Baird, 405 U.S. 438 (1972) (extending the right of privacy announced in Griswold to the use of contraception by unmarried individuals).

10. Roe v. Wade, 410 U.S. 113, 153 (1973). 
allowed exceptions when necessary to preserve the life or health of the woman. ${ }^{11}$

Roe established that under the trimester approach restrictions on pre-viability abortions would be subjected to strict scrutiny. Such restrictions would only be sustained if they were "narrowly tailored" to achieve a "compelling state interest." 12 Over the next sixteen years the application of the trimester approach and strict scrutiny led to the invalidation of a variety of abortion regulations. In the first major abortion case after Roe, Planned Parenthood v. Danforth, ${ }^{13}$ the Court struck down a number of regulations, including laws that mandated husband consent for abortions for married women, required physicians to preserve the life and health of the fetus at every stage of pregnancy, and banned the use of saline amniocentesis. ${ }^{14}$ In the 1983 case City of Akron v. Akron Center for Reproductive Health (Akron I) ${ }^{15}$ the Court invalidated regulations requiring "informed consent," waiting periods, and hospitalization for second trimester abortions. ${ }^{16}$ Three years later, in Thomburgh $v$. American College of Obstetricians and Gynecologists, ${ }^{17}$ the Court again struck down "informed consent" requirements, as well as regulations mandating the filing of detailed reports that were to be made available to the public. ${ }^{18}$

Several regulations, however, were sustained by the Court under the trimester approach. Primary among these were regulations requiring parental notification or consent before an abortion could be performed on a minor, which the Court sustained when a judicial bypass procedure was provided. ${ }^{19}$ Additionally, the Court upheld the Hyde Amendment and other restrictions on public funding of abortion, even when funding for childbirth was provided or the abortion was medically necessary. ${ }^{20}$

11. See id. at $162-64$.

12. Id. at 155 .

13. 428 U.S. 52 (1976).

14. See id. The Court also struck down' a Pennsylvania statute that required a physician to use the degree of care most likely to protect the fetus in Colautti v. Franklin, 439 U.S. 379 (1979).

15. 462 U.S. 416 (1983).

16. See id. Hospitalization requirements for second trimester abortions were also struck down in Planned Parenthood v. Ashcroft, 462 U.S. 476 (1983).

17. 476 U.S. 747 (1986).

18. See id. Thomburgh also invalidated a two physician requirement for all postviability abortions, including those performed because of a medical emergency. The Pennsylvania regulations challenged in Thornburgh were later amended and in their amended form were the abortion regulations at issue in Casey.

19. See, e.g., Ashcroft, 462 U.S. at 490-93 (striking down a notification requirement that did not include a bypass).

20. See Harris v. McRae, 448 U.S. 297 (1980) (upholding ban on funding for medically necessary abortions); Poelker v. Doe, 432 U.S. 519 (1977) (upholding ban on the use of publicly financed hospital services for abortions); Maher v. Roe, 432 U.S. 464 (1977) (upholding ban on funding for non-medically necessary abortions combined with funding for childbirth); Beal v. Doe, 432 U.S. 438 (1977) (upholding ban on funding for nonmedically necessary abortions). 
The Court's approach to abortion began to change noticeably with its decision in the 1989 case Webster v. Reproductive Health Services, ${ }^{21}$ where Justice Rehnquist's plurality opinion openly criticized the trimester approach and urged that abortion regulations only be subjected to rationality review. ${ }^{22}$ The regulations at issue in Webster declared that life begins at conception, banned the use of public employees and facilities for performing abortions, and required testing for viability at twenty weeks. Although the Court sustained the regulations, five Justices refused to use Webster as an occasion for reconsidering Roe. ${ }^{23}$ The Court upheld restrictions on minors' abortions in two cases subsequent to Webster, but again did not overturn the trimester framework of Roe. ${ }^{24}$

\section{B. Casey: The New Undue Burden Standard}

1. The Casey Opinion. - Casey involved a challenge to Pennsylvania's abortion regulations, amended in 1988 and 1989 to replace those struck down by the Court in 1986..$^{25}$ The new regulations contained the following measures: an "informed consent" requirement, which included a state-specified physician lecture; a mandatory twenty-four hour waiting period following the lecture; a husband notification requirement; an "informed" parental consent requirement; and extensive recordkeeping and reporting requirements. ${ }^{26}$ The regulations also contained exceptions from these requirements for medical emergencies, narrowly defined as conditions so dangerous that any delay would create a serious risk of substantial or irreversible harm. ${ }^{27}$

21. 492 U.S. 490 (1989) (plurality opinion).

22. See id. at 517-19. For a description of the evolution of the Court's approach to abortion, see Laurence H. Tribe, Abortion: The Clash of Absolutes 139-96 (1990).

23. See Webster, 492 U.S. at 517-19 (Rehnquist, C.J., joined by White and Kennedy, JJ., arguing for an abandonment of the Roe framework), at 525-26 (O'Connor, J., refusing to reconsider the validity of Roe), at 532-37 (Scalia, J., arguing for an overt overruling of Roe), at 537-38 (Blackmun, J., joined by Brennan and Marshall, JJ., arguing for upholding $R o e$ ), at 561 (Stevens, J., refusing to modify Roe).

24. See Ohio v. Akron Ctr. for Reprod. Health, 497 U.S. 502 (1990); Hodgson v. Minnesota, 497 U.S. 417 (1990).

25. See supra note 18 and accompanying text.

26. See $18 \mathrm{~Pa}$. Cons. Stat. Ann. §3205-09, § 3214 (Supp. 1994). As part of the mandated lecture, a physician must inform a woman seeking an abortion of the risks of pregnancy and childbirth and the probable gestational age of the fetus. In addition, the physician or an assistant must do the following: tell her that she may be eligible for medical benefits for prenatal care and childbirth; tell her that the father is liable for child support; and offer her materials prepared by the state that list agencies providing alternatives to abortion, describe the fetus, and contain depictions of the fetus at two-week gestational increments. This information need not be provided if the physician can prove she reasonably believed that doing so would have a "severely adverse effect" on the woman, and the statement about paternal liability may be omitted in cases of rape. See id. $\S 3205$. The Pennsylvania act also included a ban on sex-selection abortions. See id. $\$ 3204$ (c); infra note 130 and accompanying text.

27. See $18 \mathrm{~Pa}$. Cons. Stat. Ann. § 3203 (Supp. 1994). 
Most of these measures had previously been declared unconstitutional under Roe's trimester framework. ${ }^{28}$ In Casey, however, all of the measures except for the husband notification requirement were upheld, while the medical emergency exception was held to apply whenever compliance with the regulations would "pose a significant risk to the life or health of a woman." 29 Yet at the same time the Court maintained its continuing adherence to Roe. The Court reached this incongruous result by reading Roe's central holding as being simply the claim that women have a constitutional right to choose abortion prior to the viability of the fetus. The joint opinion, by Justices O'Connor, Kennedy, and Souter reaffirmed the Court's commitment to this right but rejected the trimester framework as "misconceiv[ing] the nature of the pregnant woman's interest ... [and] undervalu[ing] the State's interest in potential life." 30 The woman's right is "[the] right to make the ultimate decision, not to be insulated from all others in doing so." 31

In place of the trimester approach, the joint opinion adopted an undue burden standard as the test by which to judge restrictions on previability abortions. According to the joint opinion, "[a] finding of an undue burden is a shorthand for the conclusion that a state regulation has the purpose or effect of placing a substantial obstacle in the path of a woman seeking an abortion." 32 Thus, the undue burden standard is composed of two prongs, one of purpose and one of effect. In order to satisfy the purpose prong, the state cannot seek to hinder a woman's choice or enact a regulation "designed to strike at the right [to choose abortion] itself." 33 But the state is allowed to seek to persuade a woman to carry her pregnancy to term and to express a preference for childbirth. ${ }^{34}$ The effects prong is fact-sensitive; it requires a case-by-case investigation into all of the effects of a regulation, both intended and incidental. ${ }^{35}$ Further, these effects must be calculated from the perspective of those women for whom the regulation is a restriction, not by measuring its effect on all the women to whom it applies. ${ }^{36}$ A regulation may be struck down even if it only imposes a substantial obstacle on one percent of the women it affects. ${ }^{37}$ Although the undue burden standard was criticized by the six other Justices, it has become the test by which abortion regulations are

28. See notes 12-18 supra and accompanying text.

29. See Planned Parenthood v. Casey, 112 S. Ct. 2791, 2822 (1992) (majority opinion).

30. Id. at 2818 (joint opinion).

31. Id. at 2821.

32. Id. at 2820 .

33. Id. at 2819 .

34. See id. at $2818,2821$.

35. See id. at 2819-20, 2825-26, 2833.

36. See id. at 2829-30 (majority opinion).

37. See id. 
now reviewed since it represents the "narrowest grounds" on which the Justices concurred..$^{38}$

The joint opinion retained fetal viability as the crucial line for abortion regulation. The opinion argued that at the point of viability independent life becomes a realistic possibility, so that the state is justified in overriding the rights of the woman; moreover, "it might be said that a woman who fails to act before viability has consented to the State's intervention." 39 After viability, states can proscribe abortion except where necessary to preserve the life or health of the mother. Before viability, any regulation found to impose an undue burden on access to abortion is unconstitutional. But if no undue burden is found, regulations will be upheld if they are reasonable..$^{40}$ Any restriction on abortion access where a woman seeks to end a pregnancy that poses a "significant threat to [her] health" is unconstitutional. ${ }^{41}$

The Casey undue burden standard marked a shift from a bright-line test to a more subjective exercise in which judges determine the weight of a regulatory burden. Rather than simply striking down any regulations that impose more than a de minimis burden on first trimester abortions, judges must now examine the burden imposed by a regulation and determine if this burden is too heavy. ${ }^{42}$ Casey also indicated that this examina-

38. See Marks v. United States, 430 U.S. 188, 193 (1977) (holding is position taken by Justices concurring on narrowest grounds when Court is fragmented); Elizabeth A. Schneider, Comment: Workability of the Undue Burden Test, 66 Temp. L. Rev. 1003, 1004-05 (1993). Several courts have applied the undue burden standard as the Court's new test of abortion regulations. See, e.g., Barnes v. Mississippi, 992 F.2d 1335, 1339 (1993) (citing Casey as authoritative for the review of abortion regulations).

39. Casey, 112 S. Ct. at 2816-17 (joint opinion). The Court also retained viability for reasons of stare decisis. See id.

40. See id. at 2821.

41. See id. at 2822 (majority opinion).

42. See Kathryn Kolbert \& David H. Gans, Responding to Planned Parenthood v. Casey: Establishing Neutrality Principles in State Constitutional Law, 66 Temp. L. Rev. 1151, 1154-56 (1993); see also Casey, 112 S. Ct. at 2829 (majority opinion) (distinguishing between a regulation which makes abortion a little more difficult to obtain and one which imposes a substantial obstacle). The fact that some non-de minimis burdens on abortion access may be acceptable under the undue burden standard also means that challengers of abortion regulations now bear the burden of proving that regulations are unconstitutional, whereas defendants had borne the burden of proof under Roe. See Kolbert \& Gans, supra, at $\mathbf{1 1 5 5}$.

The extent to which judges will examine the burden imposed by abortion regulation will depend upon their interpretation of the scope of the Casey opinion. One possible interpretation views the opinion as offering a new standard by which abortion regulations should be judged and ruling on the constitutionality of Pennsylvania's regulations, while another perceives Casey as additionally deciding the constitutionality of certain types of abortion regulations. Compare Fargo Women's Health Org. v. Schafer, 18 F.3d 526, 530-33 (8th Cir. 1994) (suggesting that a twenty-four hour waiting period requiring two visits is not clearly constitutional after Casey) with Barnes v. Moore, 970 F.2d 12, 15 (5th Cir.), cert. denied, 113 S. Ct. 656 (1992) and Utah Women's Clinic, Inc. v. Leavitt, 844 F. Supp. 1482, 1488, 1495 (D. Utah 1994) (claiming twenty-four hour waiting periods requiring two visits are clearly constitutional after Casey). According to this second 
tion of the weight of burdens should take regulatory context into account. ${ }^{43}$ The result of this shift is a change in acceptable state purposes and the degree of scrutiny by which regulations are reviewed. ${ }^{44}$ The Court allowed state intervention not only to express a preference for childbirth but further to seek actively to persuade a pregnant woman to carry to term. This represents a notable divergence from the post-Roe insistence that "regulations designed to influence the woman's informed choice between abortion and childbirth" are unjustified. ${ }^{45}$ Casey also lowered the review accorded to abortion regulations from the strict scrutiny approach of Roe and its progeny. A restriction on pre-viability abortions no longer needs to be narrowly tailored to serve a compelling interest; rather, if the restriction does not constitute an undue burden it needs only to be reasonably related to the legitimate state interest in protecting fetal life. ${ }^{46}$

The combination of reasonableness requirements and a prohibition on undue burdens makes it difficult to determine the strength of review accorded to abortion regulations after Casey. Casey's reference to substantial obstacles as unconstitutional, and its emphasis on balancing the interests of the state and the pregnant woman, might suggest that the Court is now applying a form of intermediate scrutiny. ${ }^{47}$ But this conclusion seems unlikely given the use of rationality review to examine regulations

approach, Casey has foreclosed facial challenges to restrictions such as waiting periods and mandatory lectures. See Utah Women's Clinic, 844 F. Supp. at 1488, 1495. The frequent statements in Casey that the Court's holding was based on the record before it, and the subsequent repetition of this point by two of the joint opinion's authors, support the former interpretation. See Casey, 112 S. Ct. at 2825-26, 2833 (joint opinion); Planned Parenthood v. Casey, 114 S. Ct. 909, 911 (1994) (Souter, J., denying stay of mandate); Fargo Women's Health Org. v. Schafer, 113 S. Ct. 1668, 1669 (1993) (O'Connor, J., concurring in denial of stay). At a minimum, these comments suggest that the Court was allowing for the possibility that in some contexts certain regulations, such as the waiting period requirement, might not be constitutional. Compare Casey, 112 S. Ct. at 2824 (joint opinion) with id. at 2825-26.

43. See Casey, 112 S. Ct. at 2825-26, 2833 (joint opinion), at 2845 (Blackmun, J., concurring in part and dissenting in part), at 2880 (Scalia, J., concurring in the judgment in part and dissenting in part) (comments limiting holding to record before the Court).

44. See Martha A. Field, Abortion Law Today, 14 J. Legal Med. 3, 11-13 (1993).

45. City of Akron v. Akron Ctr. for Reprod. Health (Akron I), 462 U.S. 416, 444 (1983).

46. See Casey, 112 S. Ct. at 2821 (joint opinion).

47. See id. at 2805-07 (majority opinion), at 2816-20 (joint opinion). Sullivan implies that the Court may be applying such an intermediate scrutiny approach, although she notes that lesser burdens are only subjected to rationality review. See Kathleen $M$. Sullivan, The Supreme Court, 1991 Term-Foreword: The Justices of Rules and Standards, 106 Harv. L. Rev. 22, 33-34 \& n.70, 60-62 (1992) [hereinafter Sullivan, Supreme Court]; see also Richard H. Fallon, Jr., Some Confusions About Due Process, Judicial Review, and Constitutional Remedies, 93 Colum. L. Rev. 309, 315 (1993). For a definition of intermediate scrutiny see Mississippi Univ. for Women v. Hogan, 458 U.S. 718, 724 (1982) (intermediate scrutiny requires that regulations serve "important governmental objectives and that the discriminatory means employed [are] ... substantially related to the achievement of those objectives"). 
imposing burdens not considered to be substantial obstacles. ${ }^{48}$ It is particularly noteworthy that Casey appeared to allow states to impose restrictions on abortion not amounting to undue burdens in order to achieve a legitimate interest, as opposed to the important or substantial state interest requirement usually employed under intermediate scrutiny. ${ }^{49}$ In practice, the strength of the scrutiny applied to abortion regulations will depend on how high a threshold the Court sets for a finding of undue burden. If this threshold is low, the strength of review will be more like intermediate scrutiny, since a greater number of regulations would be examined searchingly. That the Court upheld almost all of the regulations challenged in Casey suggests that the Court will in fact set a high threshold and perhaps only find a substantial obstacle when a regulation serves as the equivalent of outlawing abortion for those women it affects. ${ }^{50}$ If such a high threshold is used, most regulations will be upheld and the undue burden standard will collapse into little more than rationality review.

The claim that Casey offers less than intermediate scrutiny is buttressed by the absence of any balancing in the abortion undue burden standard. A central characteristic of the Court's usual approach to standards that require "due" treatment is a balancing of the countervailing interests and values at stake in a particular context. In its due process jurisprudence, for instance, the Court has distinguished between the pro-

48. In general, rationality review is less demanding than intermediate scrutiny. Government purposes need only be legitimate, and the regulation merely reasonably related to achieving them. See Williamson v. Lee Optical Co., 348 U.S. 483 (1955). Moreover, the Court has applied rationality review very deferentially, asking only if the regulation could be valid under a hypothetical state of facts and not requiring that the stated purpose actually have motivated the legislature. See Hodel v. Virginia Surface Mining \& Reclamation Ass'n, 452 U.S. 264, 276-77 (1981); Laurence H. Tribe, American Constitutional Law 1439-43 (2d ed. 1988). However, the Court has on occasion developed a more searching, rationality-with-bite approach that it has applied in the substantive due process and equal protection context. For a discussion of the rationality-with-bite approach and its applicability to the abortion context, see infra notes 188-191 and accompanying text.

49. The Court's comments on this point are inconsistent. On the one hand, the Court claimed that the state "has a substantial interest in potential life," Cascy, $112 \mathrm{~S}$. C. at 2820 (joint opinion), while at others it referred to Roe for the proposition that the state has a "legitimate interest in promoting the life or potential life of the unborn." Id. at 2817. Since the Casey joint opinion criticizes the weight given to the state's interest in potential life in Roe and its progeny, see id. at 2817-20, a comparison of these comments alone would suggest that the Court is replacing Roe's strict scrutiny with heightened scrutiny, and reclassifying the interest in potential life as substantial. But these comments must be integrated into the rest of the joint opinion, in particular the acceptance of regulations serving "a valid purpose" so long as they do not create undue burdens and the fact that the Court did not require substantial interests when it applied the standard. For example, the Court upheld the record-keeping requirements without any examination of the strength of the state's interest in health. See id. at 2832-33. Justice Blackmun interpreted the joint opinion as allowing restrictions on abortion to serve interests deemed only legitimate. See id. at 2849 (Blackmun, J., dissenting in part).

50. See Casey, 112 S. Ct. at 2829 (majority opinion). 
cess due a welfare recipient before benefits are revoked and that due a disability recipient, based on such contextual factors as the urgency of need and the types of evidence at issue. ${ }^{51}$ Indeed, the use of balancing is implied by the very term "undue burden," which suggests an examination of the justifications offered in defense of a regulation as well as of the extent of its effects. Despite this jurisprudential precedent and linguistic implication, the abortion undue burden standard only analyzes the quantity of burdens imposed. An abortion regulation that is found to impose a burden amounting to a substantial obstacle is unconstitutional, regardless of the benefits it also may bring; correspondingly, a regulation that is found not to impose a substantial obstacle is upheld no matter how few benefits it brings, provided it is rational. 52

The absence of any balancing in the abortion undue burden standard weakens the strength of judicial scrutiny because it means there is little protection against two types of burdens. The first are burdens that do not amount to substantial obstacles but are more burdensome than necessary to realize a legitimate purpose. Protection against such unnecessary but not undue burdens would require an examination of alternative abortion regulations, since otherwise it is difficult to discern that a regulatory burden is avoidable. However, the undue burden standard forecloses such an examination; a rational regulation that does not create a substantial obstacle to abortion access is upheld even if an alternative regulation would be equally effective but less burdensome.

The second type are burdens that neither amount to substantial obstacles nor are unnecessary, yet serve less important legislative goals such as administrative convenience. ${ }^{53}$ In order to provide protection against such "unjustified" burdens the Court must balance the importance of the legislative goal against the significance of the burdened interest. Rationality review fails to protect against such burdens because it only prohibits arbitrary regulations that serve no legitimate purpose and provides no means of determining the relative importance of legislative goals.

51. See Mathews v. Eldridge, 424 U.S. 319, 335, 340-42 (1976); Goldberg v. Kelly, 397 U.S. 254, 260-64 (1970). Such balancing also figures in the Court's examination of undue burdens in the dormant Commerce Clause area, see infra notes 95-98 and accompanying text. For a discussion of the problems with balancing as a mode of constitutional analysis, see generally T. Alexander Aleinikoff, Constitutional Law in the Age of Balancing, 96 Yale L. J. 943 (1987).

52. It could be argued that the joint opinion adopted a balancing approach in crafting the undue burden standard, balancing the woman's liberty interest and concerns of stare decisis with the state's interest in potential life. See Casey, 112 S. Ct. at 2805-06 (majority opinion), at 2816-17 (joint opinion); Sullivan, Supreme Court, supra note 47, at 79-81. But this use of balancing in crafting the undue burden standard did not extend to employing balancing in applying the standard, as is demonstrated by the lack of protection against unnecessary but not undue burdens.

53. See, e.g., Reed v. Reed, 404 U.S. 71, 76 (1971) (holding that while administrative convenience is a legitimate governmental objective, it does not justify the use of gender stereotypes). 
2. The Weaknesses in the Undue Burden Standard. - Casey thus established a new analytic framework, the undue burden standard, by which abortion regulations would henceforth be judged. But although the joint opinion outlined the theoretical form of the standard and defended its underlying principles, the opinion offered little guidance on how the standard should be applied. In the words of Justice Scalia, after highlighting certain facts in the record, "the opinion then simply announces that the provision either does or does not impose . . . an 'undue burden.' "54 For example, the opinion failed to explain how the effects of regulations should be calculated, how much of an effect is necessary for a finding of undue burden, or what types of effects are relevant. In addition, the purpose prong received strikingly little attention. The opinion failed to indicate how regulations "calculated to inform the woman's free choice" will be differentiated from those calculated to "hinder it." failure is notable given that any attempt to "inform" the woman's choice will likely include measures that have the effect of at least temporarily hindering this choice.56 In short, Casey provided no methodology for identifying a purpose to create an undue burden or for determining when a regulation creates an undue burden through its effects. ${ }^{57}$

The lack of guidance about how to apply the undue burden standard is worsened by inconsistencies in the joint opinion. The Court referred to empirical studies of domestic violence in striking down the husband notification requirement, but made no reference to the empirical evidence of the harmful effects of parental consent requirements. ${ }^{58}$ Indeed, it did not examine the factual record at all in sustaining the informed parental consent requirement. ${ }^{59}$ Perhaps most notably, the Court acknowledged the extensive evidence in the record of the burdens imposed by waiting periods, but nonetheless upheld the waiting period requirement on the grounds that the district court had not specifically found

54. Casey, 112 S. Ct. at 2880 (Scalia, J., concurring in the judgment in part and dissenting in part).

55. See id. at 2820 (joint opinion).

56. See id. at 2877 (Scalia, J., concurring in the judgment in part and dissenting in part); Field, supra note 44, at 14-15.

57. The approach to the undue burden standard taken by Blackmun and Stevens provides additional confusion for judges seeking guidance in applying the undue burden standard. Stevens argued that the waiting period and "informed consent" requirements failed rationality review, and Blackmun argued that the joint opinion "erred" in sustaining most of the provisions. See Casey, 112 S. Ct. at 2842-43 (Stevens, J., concurring in part and dissenting in part), at 2845 (Blackmun, J., concurring in part and dissenting in part).

58. See The Supreme Court, 1991 Term: Leading Cases, 106 Harv. L. Rev. 163, 206-10 (1992) [hereinafter The Supreme Court, 1991 Term]. Several of the amici briefs submitted in Casey provided evidence of the harmful effects of parental consent and notification requirements. See, e.g., Brief Amici Curiae of the Alan Guttmacher Institute et al. at 7-8, 12, Casey, 112 S. Ct. at 2791 (Nos. 91-744, 91-902); Brief Amici Curiae of the NAACP Legal Defense \& Educ. Fund, Inc. et al. at 25-29, id.

59. See Casey, 112 S. Ct. at 2832 (joint opinion). 
that this requirement would create a substantial obstacle. ${ }^{60}$ In addition, the joint opinion argued that the husband notification requirement relied on a conception of women as subject to their husbands' authority, a conception that is "repugnant to our present understanding of marriage and of the nature of the rights secured by the Constitution."61 Yet the opinion discounted the restrictive understanding of women's decisional autonomy that underlay the state mandated lecture and waiting period requirements. ${ }^{62}$

Casey's methodological deficiencies cannot be rectified by reference to earlier enunciations of the undue burden standard. Justice O'Connor had been arguing for the undue burden standard since her dissent in Akron I in 1983. ${ }^{63}$ But the Casey undue burden standard differs signifcantly from the version O'Connor developed in Akron I. Her earlier formulation defined an undue burden as an "absolute obstacle[ ] or severe limitation [ ]" and did not inquire into the purpose of a regulation until after the existence of such a burden had been proven. ${ }^{64}$ Moreover, the question of whether an undue burden existed was only a threshold inquiry; after finding an undue burden, O'Connor then applied strict scrutiny to determine whether the undue burden was justified.65 In Casey the Court explicitly acknowledged the transformation of the undue burden standard from its previous incarnation, stating that despite earlier suggestions " $[i] n$ our considered judgment, an undue burden is an unconstitutional burden." 66 Nor can a method for applying the undue burden standard be drawn from other abortion cases. Although Casey argued that the undue burden standard had been applied in earlier cases, ${ }^{67}$ there seems to be little support for this claim. Several cases used the term "undue burden"; however, none articulated a standard of review. ${ }^{68}$ The term

60. See id. at $2825-26$.

61. Id. at 2831 (majority opinion).

62. See id. at 2841-42 (Stevens, J., concurring in part and dissenting in part); Field, supra note 44 , at 14 n.39.

63. 462 U.S. 416, 453, 462-66 (1983) (O'Connor, J., dissenting); see also Hodgson v. Minnesota, 497 U.S. 417, 459 (1990) (O'Connor, J., concurring in part); Webster v. Reproductive Health Servs., 492 U.S. 490, 529-30 (1989) (O'Connor, J., concurring in part); Thornburgh v. American College of Obstetricians \& Gynecologists, 476 U.S. 747, 828 (1986) (O'Connor, J., dissenting).

64. See Akron $I, 462$ U.S. at 463-64.

65. See id. at 463; see also Susan R. Estrich \& Kathleen M. Sullivan, Abortion Politics: Writing for an Audience of One, 138 U. Pa. L. Rev. 119, 133-35 (1989).

66. Casey, 112 S. Ct. at 2820 (joint opinion).

67. See id. at 2819. But see id. at 2866 (Rehnquist, C.J., concurring in the judgment in part and dissenting in part) (undue burden standard "created largely out of whole cloth"); id. at 2876 n.3 (Scalia, J., concurring in part and dissenting in part) (earlier cases did not use undue burden standard).

68. See Bellotti v. Baird (Bellotti II), 443 U.S. 622, 647 (1979) (parental consent statute imposes "undue burden" as construed by Massachusetts Supreme Court); Maher v. Roe, 432 U.S. 464, 473-74 (1977) (woman protected from "unduly burdensome" interference with right to seek abortion); see also Harris v. McRae, 448 U.S. 297, 314 (1980) (quoting Maher's formulation). 
was used repeatedly in only one case, Bellotti v. Baird (Bellotti I), but again without any theoretical development. ${ }^{69}$

It might be argued, as Justice Stevens did, that Casey's failure to enunciate the details of the undue burden standard is not problematic because such details will emerge over time. ${ }^{70}$ But in fact the lack of a methodology for applying the standard has serious consequences. First, it leads to unconstrained judicial discretion. To some extent, increased judicial discretion is inherent in any highly fact-based standard. ${ }^{71}$ The absence of a systematic methodology, however, expands the realm of discretion significantly, since judges determine what evidence is relevant and how it should be weighed. Such extreme discretion can serve to undercut the Court's legitimacy, which as the Casey opinion recognized, depends on the belief that the Court's decisions are grounded in principles. 72

Moreover, the failure to develop a methodical analysis of the undue burden standard perpetuates the inconsistency of rulings on abortion. Casey aimed, at least in part, to provide guidance for lower courts struggling to apply an incoherent post-Webster abortion doctrine to a multitude of new abortion regulations. ${ }^{73}$ The lack of a methodology for applying the undue burden standard means that the inconsistency in lower court rulings will continue, as seen in post-Casey decisions. For example, a facial challenge to a twenty-four hour waiting period requirement in North Dakota was allowed, while a similar challenge was dismissed in Utah as frivolous. ${ }^{74}$ Despite Casey's repeated reference to ruling only on the record before it, some courts have refused to engage in a factual analysis of abortion regulations and instead simply have applied Casey's specific

69. 428 U.S. 132 (1976). Bellotti I represented a challenge to Massachusetts' parental consent law. In holding that the district court should have abstained pending construction of the statute by the state courts, Justice Blackmun argued that "a requirement of written consent . . . is not unconstitutional unless it unduly burdens the right to seek an abortion." Id. at 147 (emphasis added). However, Blackmun used the term "undue burden" as a shorthand for the Court's earlier decision in Planned Parenthood v. Danforth, 428 U.S. 52 (1976), and never indicated that he meant to replace the Roe trimester framework with a new standard. In addition, since the Court's decision turned on abstention doctrine and not on the acceptability of the statute, Bellotti I provides little clarification of how undue burdens should be measured. part).

70. See Casey, 112 S. Ct. at 2843 n.6 (Stevens, J., concurring in part and dissenting in

71. See id. at 2848 (Blackmun, J., concurring in part and dissenting in part); Sullivan, Supreme Court, supra note 47 , at 58-59.

72. See Casey, 112 S. Ct. at 2814 (majority opinion).

73. See id. at 2803-04.

74. See Fargo Women's Health Org. v. Schafer, 18 F.3d 526, 534-35 (8th Gir. 1994) (allowing facial challenge, although ultimately sustaining waiting period requirement); Utah Women's Clinic, Inc. v. Leavitt, 844 F. Supp. 1482, 1487, 1495 (D. Utah 1994) (stating that " $[\mathrm{b}]$ ecause the two visit requirement is constitutional in Pennsylvania, it must also be constitutional in Utah" and ordering plaintiffs to pay costs for frivolous lawsuit). 
holdings. ${ }^{75}$ Yet regulations that are not burdensome in Pennsylvania may well be burdensome in other states where there are fewer abortion providers or a more rural and poorer population. Thus some women may be denied effective exercise of their constitutional right to choose abortion.

\section{Three Constitutional Models: Potential Sources of a Methodology for the Undue Burden Standard}

A comparison of the undue burden standard to three other constitutional approaches provides a methodology for applying the undue burden standard and highlights the inadequacies of the standard as enunciated in Casey. These approaches are the two-tiered inquiry of the dormant Commerce Clause, the content-neutral, traditional forum analysis applied to regulations on expression, and the endorsement test of the Establishment Clause. Two questions, in particular, could be raised about this comparative analysis. First, why is the Court's approach in other constitutional areas relevant to developing a methodology for applying the undue burden standard? Second, accepting that the Court's approach in other constitutional areas might be relevant, why focus on these three models?

The first question is based on the belief that the tests the Court applies in different areas reflect concerns that are specific to that area and cannot simply be transplanted. The strongest argument for this claim is Casey's description of abortion as a "unique act," different from other private choices because of its effect on the fetus, the woman's family and society. ${ }^{76}$ Yet while Casey acknowledged that abortion is unique in this sense, the opinion denied that the right to choose abortion is distinct from the rest of constitutional jurisprudence. Rather, it situated the abortion right at the intersection of two important lines of decisions upholding individual rights, those relating to bodily integrity and to reproductive and familial autonomy. ${ }^{77}$ Casey also indicated the relevancy of comparison to other areas of jurisprudence by drawing on models used in other areas to justify the undue burden standard. ${ }^{78}$

75. See, e.g., Barnes v. Moore, 970 F.2d 12, 15 (5th Cir.), cert. denied, 113 S. Ct. 656 (1992) (Mississippi statute sufficiently similar to Pennsylvania's so as to preclude the need for further evidentiary proceedings); see also supra note 42 .

76. See Casey, 112 S. Ct. at 2807 (majority opinion).

77. See id. at 2810-11 (citing Cruzan v. Director, Mo. Dep't of Health, 497 U.S. 261, 278 (1990), for bodily integrity doctrine, Griswold v. Connecticut, 381 U.S. 479 (1965), for reproductive autonomy, and Carey v. Population Servs., Int'l, 431 U.S. 678 (1977), for familial autonomy).

78. See id. at 2818 (joint opinion) (citing Anderson v. Celebrezze, 460 U.S. 780, 788 (1983), where early filing requirements for independent candidates were invalidated). The Court's language suggests that the use of the undue burden standard serves to make review of abortion regulations more similar to review of other fundamental rights. See id. ("As our jurisprudence relating to all liberties save perhaps abortion has realized, not every law which makes a right more difficult to exercise is, ipso facto, an infringement of that right.") Some commentators have questioned this claim, arguing that fundamental rights 
In addition, it is important to distinguish between the standard used in an area of jurisprudence and the methods for applying that standard. Occasionally such methods may arise from concerns peculiar to a particular constitutional provision. ${ }^{79}$ More often, however, the analytical methods apply to other areas of law, provided an appropriate rationale is present. A central example is the Court's use of the strict scrutiny methodology. Initially developed as a means of determining whether legislation unconstitutionally distinguished among members of different races, strict scrutiny was then expanded to apply to fundamental rights and adapted to address gender discrimination. 80

A similar criticism might be that developing a systematic methodology de novo is better than extrapolating methods from other areas. However, adapting existing analytical methods has the advantage that the Court is already familiar with these methods and has already explored the details of their application. As a result, the Court can use accepted methods from other constitutional approaches to immediately systematize a new standard. Adaptation of existing analytical methods also preserves the consistency of constitutional jurisprudence as a whole, thereby enhancing the court's ability to claim that its decisions are principled and not simply ad hoc in nature. ${ }^{81}$

The second question relates to the selection of the dormant Commerce Clause inquiry, the content-neutral, traditional forum analysis and the endorsement test as comparisons to the undue burden standard. Casey emphasized that the results reached by applying the undue burden standard would be dependent on the specific facts of a case. Each of these comparison approaches similarly involves a case-by-case, fact-intensive analysis. The Casey opinion also defined the undue burden standard as a two-pronged, purpose and effect inquiry. Dormant Commerce Clause analysis and the endorsement test represent purpose and effect inquiries. Finally, the crux of Casey is the application of an undue burden standard to abortion regulations. Dormant Commerce Clause analysis represents the predominant use of an undue burden standard in consti-

are generally protected by strict scrutiny, which the undue burden standard explicitly disallows. See Schneider, supra note 38, at 1028-29; Fallon, supra note 47, at 315.

79. One example is the overbreadth doctrine of the First Amendment, which allows individuals to challenge laws restricting freedom of expression on the grounds that the laws would be unconstitutional as applied to third parties. The Court made an exception to the general prohibition on asserting the rights of third parties out of fear that the law may have a chilling effect on protected speech. See Gerald Gunther, Constitutional Law 1191-92 \& nn.4-5 (12th ed. 1991).

80. See Korematsu v. United States, 323 U.S. 214 (1944) (specifying strict scrutiny for race); Shapiro v. Thompson, 394 U.S. 618, 634 (1969) (applying strict scrutiny to the fundamental right to vote); Mississippi Univ. for Women v. Hogan, 458 U.S. 718 (1982) (applying intermediate scrutiny for gender).

81. Several commentators adopt holistic or thematic approaches to the Constitution and to adjudication generally. See Ronald Dworkin, Law's Empire 410-13 (1986); Cass R. Sunstein, Naked Preferences and the Constitution, 84 Colum. L. Rev. 1689, 1689-93 (1984) [hereinafter Sunstein, Naked Preferences]; Tribe, supra note 48, at 1-22. 
tutional jurisprudence prior to Casey. All three comparison approaches also resemble the abortion undue burden standard in that they can be categorized as, at best, a form of intermediate scrutiny. Methods employed in these approaches thus can be extrapolated to the abortion context without reinserting strict scrutiny into the Court's review of abortion regulations. ${ }^{82}$ These approaches therefore serve as useful comparisons to the Casey undue burden standard. ${ }^{83}$

\section{The Dormant Commerce Glause and the Undue Burden STANDARD}

Under the dormant Commerce Clause doctrine the Court engages in a two-tiered, fact-sensitive inquiry that analyzes the purpose and effect of state regulations and determines whether these regulations constitute an undue burden on interstate commerce. An examination of this inquiry demonstrates the comparative weakness of the abortion undue bur-

82. For a description of the dormant Commerce Clause and traditional forum approaches as instances of intermediate scrutiny, see Sullivan, Supreme Court, supra note 47, at 61 . While it might be argued that strict scrutiny applies under the Establishment Clause, the endorsement test appears to use a more intermediate form of review in that it allows accommodations of religion that do not amount to endorsement. See Lynch v. Donnelly, 465 U.S. 668, 691-92 (1984) (O'Connor, J., concurring). The level of scrutiny applied under the Casey undue burden standard as a whole is less than intermediate scrutiny, since unnecessary but not undue burdens and unjustified burdens are only subjected to rationality review. See supra notes 47-53 and accompanying text. Even so, the methods extrapolated from these approaches do not increase the scrutiny of abortion regulations beyond the strength of review indicated in Casey. These methods are used in determining whether or not an undue burden exists, rather than in reviewing regulations found not to constitute an undue burden.

83. These three analyses also are more appropriate comparisons than other similar standards used in constitutional jurisprudence. For example, while Takings Clause analysis requires a highly fact-specific inquiry into the extent of a burden on an individual, see Kaiser Aetna v. United States, 444 U.S. 164, 175 (1979), the multi-dimensional character of property rights differs substantially from the indivisible liberty interest in abortion. Further, while the Court may uphold regulations that substantially burden property if such regulations can be said to provide benefits to the owner as well, see Agins v. City of Tiburon, 447 U.S. 255, 262 (1980), only under a paternalistic approach can substantial interference be said actually to benefit pregnant women seeking an abortion. The approach used in conjunction with the Free Exercise clause might seem analogous to the abortion undue burden; however, under the Free Exercise clause even substantial incidental burdens are considered constitutional, whereas according to the undue burden standard incidental burdens are unconstitutional if they create substantial obstacles. Compare Planned Parenthood v. Casey, 112 S. Ct. 2791, 2820 (1992) (joint opinion) with Employment Div., Dep't of Human Resources of Or. v. Smith, 494 U.S. 872, 890 (1990). Lastly, the undue burden standard might be compared to equal protection analysis, which also utilizes a purpose and effect inquiry. But equal protection analysis requires a finding of both discriminatory purpose and discriminatory effect, whereas either a purpose or effect of creating substantial obstacles violates the undue burden standard. Compare Casey, 112 S. Ct. at 2820 with Washington v. Davis, 426 U.S. 229, 241-42 (1976). In addition, under equal protection analysis, the aim is to determine whether a comparative difference in effect exists, whereas under the undue burden standard the focus is on the quantitative effect. 
den standard, particularly in regard to unnecessary but not undue burdens. This examination also suggests three techniques that could be incorporated into a methodology for applying the abortion undue burden standard: the per se rule against facial discrimination, the surrogacy test, and the cumulative effects principle.

\section{A. The Two-Tiered Inquiry of the Dormant Commerce Clause}

Ever since 1824 the Supreme Court has viewed Congress' constitutional power to regulate interstate commerce as implicitly limiting the states' regulatory ability. ${ }^{84}$ These limits, which developed into the dormant Commerce Clause doctrine, have undergone several permutations over the years and have become increasingly potent restrictions on state legislation. ${ }^{85}$ The classic statement of the Court's current dormant Commerce Clause doctrine was offered in Pike v. Bruce Church, Inc.:86

Where the statute regulates even-handedly to effectuate a legitimate local public interest, and its effects on interstate commerce are only incidental, it will be upheld unless the burden imposed on such commerce is clearly excessive in relation to the putative local benefits. If a legitimate local purpose is found, then the question becomes one of degree. And the extent of the burden that will be tolerated will of course depend on the nature of the local interest involved, and on whether it could be promoted as well with a lesser impact on interstate activities. ${ }^{87}$

The current analysis can be seen as composed of two tiers of review. ${ }^{88}$ The first tier determines if a state statute discriminates against interstate commerce or regulates interstate commerce directly, in which case the statute is generally declared to be invalid without further examination. ${ }^{89}$ The rationale for the virtual per se invalidity of discriminatory legislation is that such discrimination, when it represents economic protectionism

84. See Gibbons v. Ogden, 22 U.S. (9 Wheat.) 1 (1824).

85. See, e.g., Southern Pac. Co. v. Arizona ex rel. Sullivan, 325 U.S. 761, 781 (1945) (state regulations constitutional where state interest outweighs burden on interstate commerce); Smith v. Alabama, 124 U.S. 465, 482 (1888) (state regulations with only an indirect impact on interstate commerce are constitutional); Cooley v. Board of Wardens, 53 U.S. (12 How.) 299, 320-21 (1851) (states may regulate where local subject matter and uniformity are not required).

86. 397 U.S. 137 (1970).

87. Id. at 142 (citations omitted). The fact that dormant Commerce Clause doctrine requires "even-handed" regulations, whereas the abortion undue burden standard allows a state to express a preference for childbirth, does not prevent a useful comparison between these two standards. Both approaches are concerned with identifying illegitimate purposes, namely economic protectionism and discrimination in the former area and intentional creation of substantial obstacles in the latter. See text accompanying notes 101-104.

88. See Brown-Forman Distillers Corp. v. New York State Liquor Auth., 476 U.S. 573, 578-79 (1986).

89. See id. at 579. For examples of this first-tier review, see Oregon Waste Sys., Inc. v. Department of Envtl. Quality, 114 S. Ct. 1345, 1350 (1994); City of Philadelphia v. New Jersey, 437 U.S. 617,624 (1978). 
against other states, strikes at the heart of national union. ${ }^{90}$ Not all discriminatory legislation is protectionist, however. Given the interdependence of state and national economies and the different economic specializations of states, many state regulations could burden out-of-state interests more than in-state. ${ }^{91}$ As a result, the first-tier rule of per se invalidity applies mainly to statutes that the Court believes were motivated by economic protectionism or that embody such discrimination on their face.92 Statutes that serve a legitimate purpose but facially discriminate against interstate commerce are upheld only if non-discriminatory alternatives are unavailable. ${ }^{93}$ Statutes that have clear discriminatory effects without a clear discriminatory purpose are subjected to second-tier balancing, but the state bears the burden of justifying the legislation. ${ }^{94}$

The Court moves to the second tier of review if the statute is deemed "even-handed," advancing a "legitimate," non-discriminatory interest and imposing only "incidental" burdens on interstate commerce. Here the Court claims to apply a balancing approach, weighing the burden the statute places on interstate commerce against the local benefits it brings. ${ }^{95}$ In its balancing process, the Court considers whether less burdensome alternatives are available but is reluctant to challenge a state legislature's assessment of the utility of legislation. ${ }^{96}$ Some commentators have argued that despite its stated doctrine, the Court does not in fact utilize second-tier balancing in most dormant Commerce Clause cases. $^{97}$ Nonetheless, second-tier balancing continues to play an impor-

90. According to the Court, economic protectionism is incompatible with the "principle that our economic unit is the Nation," H.P. Hood \& Sons v. Du Mond, 336 U.S. 525,537 (1949), and the constitutional principle "that the peoples of the several states must sink or swim together," Baldwin v. G.A.F. Seelig, Inc., 294 U.S. 511,523 (1935). See also Donald H. Regan, The Supreme Court and State Protectionism: Making Sense of the Dormant Commerce Clause, 84 Mich. L. Rev. 1091, 1112-15 (1986) (economic protectionism is theoretically and practically incompatible with national union).

91. See Regan, supra note 90, at 1163; Michael E. Smith, State Discriminations Against Interstate Commerce, 74 Cal. L. Rev. 1203, 1208 (1986).

92. See Smith, supra note 91, at 1239-46.

93. See C \& A Carbone, Inc. v. Town of Clarkstown, 114 S. Ct. 1677, 1683 (1994); Hughes v. Oklahoma, 441 U.S. 322, 336 (1979). Since it is possible for discriminatory legislation to be upheld, the first tier of review is known as embodying virtual per se invalidity. (1977).

94. See Hunt v. Washington State Apple Advertising Comm'n, 432 U.S. 333, 353

95. See Brown-Forman Distillers Corp. v. New York State Liquor Auth., 476 U.S. 573, 579 (1986). For examples of this second tier of review, see Kassel v. Consolidated Freightways Corp., 450 U.S. 662, 670-79 (1981); Hunt, 432 U.S. at 351-54; Pike v. Bruce Church, Inc., 397 U.S. 137, 142-46 (1970).

96. See Minnesota v. Clover Leaf Creamery Co., 449 U.S. 456, 463-64, 470 (1981) ("States are not required to convince the courts of the correctness of their legislative judgments."). Where the Court has struck down statutes on the grounds that less burdensome alternatives are available, there often has been evidence of discrimination.

See Hunt, 432 U.S. at 350-51; Dean Milk Co. v. City of Madison, 340 U.S. 349, 354 (1951).

97. Donald Regan has offered the most important attack on second-tier balancing. According to Regan, the only coherent rationale for striking down state regulations on 
tant role in transportation and tax cases, and occasionally also surfaces in movement-of-goods cases. ${ }^{98}$ When the Court strikes down state legislation on dormant Commerce Clause grounds under either tier, it does so claiming that its inquiry determined that the legislation is an "undue burden" on interstate commerce.

\section{B. A Comparison of the Two-Tiered Dormant Commerce Clause Inquiry and the Undue Burden Standard}

A comparison of the dormant Commerce Clause analysis and abortion undue burden standard demonstrates notable similarities in the approaches the Court uses in these two areas, as well as some significant differences. The most overt similarity is that in both areas the Court strikes down statutes on the grounds that they impose an "undue burden." Thus, for each, the conclusion that the statute creates an undue burden is enough to deem it unconstitutional. ${ }^{99}$ In addition, although the Court does not describe the dormant Commerce Clause approach as a purpose and effects inquiry, the two-tiered review effectively performs such an analysis. The first tier constitutes an investigation into whether

dormant Commerce Clause grounds in movement of goods cases is that the regulations were motivated by a protectionist purpose. See Regan, supra note 90, at 1092, 1101-27. Justice Scalia also has attacked the balancing aspect of dormant Commerce Clause analysis for its lack of textual basis in the Constitution and its unsuitability for the judicial function. See Bendix Autolite Corp. v. Midwesco Enters., 486 U.S. 888, 896-98 (1988) (Scalia, J., concurring); Tyler Pipe Indus. v. Washington State Dep't of Revenue, 483 U.S. 232, 265, 259-65 (1987) (Scalia, J., concurring in part and dissenting in part). For other critical approaches to the dormant commerce clause that offer more radical solutions, see Julian N. Eule, Laying the Dormant Commerce Clause to Rest, 91 Yale L.J. 425, 442-43, 446-57 (1982) (arguing that dormant Commerce Clause analysis should be dispensed with altogether in favor of Article IV Privileges and Immunities Clause); Martin H. Redish \& Shane V. Nugent, The Dormant Commerce Clause and the Constitutional Balance of Federalism, 1987 Duke L.J. 569, 591-98, 606-12 (same).

98. Regan explicitly acknowledges balancing plays a role in transportation and tax cases. See Regan, supra note 90, at 1104 . One movement-of-goods case where the Court chose to engage in balancing, rather than pursue an inquiry into discriminatory purpose, is Bendix, 486 U.S. at 891 ("The Ohio statute before us might have been held to be a discrimination that invalidates without extended inquiry. We choose, however, to assess the interests of the State .... ). See also Aleinikoff, supra note 51, at $966 \mathrm{n} .143$ (arguing that despite Regan's claims, the Court does balance state interests against the burden on interstate commerce in some "movement-of-goods" cases).

99. Therefore, by clarifying that an undue burden is an unconstitutional burden in Casey, see Planned Parenthood v. Casey, 112 S. Ct. 2791, 2820-21 (1992) (joint opinion), the joint opinion brought abortion undue burden analysis into line with this aspect of the Court's use of undue burden in the dormant Commerce Clause area. Dormant Commerce Clause jurisprudence represented the primary use of undue burden analysis prior to Casey. The other uses of the term "undue burden" were primarily cases relating either to discovery orders, see Fed. R. Civ. P. 26(c), or to the effect of due process requirements on government, see Logan v. Zimmerman Brush Co., 455 U.S. 422, 435 (1982); see also Youngberg v. Romeo, 457 U.S. 307, 321 (1982) (requiring compelling interest for restriction of mental patients would be an "undue burden" on the state). In neither type of case has the term been used extensively or to represent a standard. 
the purpose of the legislation was to discriminate against interstate commerce, while the second tier represents an examination of the effects of the legislation on interstate commerce. Similarly, Casey established a purpose and effects inquiry to determine whether a regulation imposed an undue burden on a woman seeking an abortion. ${ }^{100}$

Under both the dormant Commerce Clause and abortion undue burden standards, a statute will be deemed unconstitutional if it is enacted to serve a purpose that is not "legitimate" or "valid."101 Both define an illegitimate purpose as one that directly undermines the right involved, where the resulting effects cannot be deemed "incidental." 102 In dormant Commerce Clause doctrine, the illegitimate purpose is economic protectionism and discrimination; in the abortion context, it is the intentional creation of substantial obstacles in the path of a woman seeking to abort a nonviable fetus. Moreover, in neither context has the Court indicated the extent to which an illegitimate purpose must be present in order to invalidate a statute. Under dormant Commerce Clause analysis the Court will sometimes invalidate laws when there is any evidence of an illegitimate purpose, but on other occasions move to second tier balancing despite such evidence. ${ }^{103}$ Casey similarly provided little guidance on how prominent an illegitimate purpose must be before an abortion restriction can be struck down.

One difference between the purpose requirements of the two standards is that in the abortion context the state does not need to be evenhanded. Rather, it can express a preference for childbirth and adopt measures to further its interest in potential life, provided that these measures do not create substantial obstacles to abortion access. This difference does not prevent a comparison of the two standards, since both involve determining whether an illicit purpose exists. Casey's apparent

100. See supra text accompanying notes $32-37$.

101. Compare Casey, $112 \mathrm{~S}$. Ct. at 2819 (joint opinion) (statute must serve a valid purpose) with Pike v. Bruce Church, Inc., 397 U.S. 137, 142 (1970) (statute must serve a legitimate public interest).

102. Compare Casey, 112 S. Ct. at 2819 (joint opinion) (law which has incidental effects not amounting to an undue burden is constitutional) with Pike, 397 U.S. at 142 (effects on interstate commerce must be only incidental).

103. Compare C \& A Carbone, Inc. v. Town of Clarkstown, 114 S. Ct. 1677 (1994) (striking down on first tier review a town's requirement that all nonhazardous waste be processed at a facility within the town although the requirement could be seen as a means of financing a public enterprise rather than as a means of fostering local businesses) with Kassel v. Consolidated Freightways Corp., 450 U.S. 662 (1981) (striking down on second tier review a state limitation on the length of trucks, although the statute could be seen as protectionist because it contained exemptions for local businesses). One reason why the Court may not have felt it necessary to address the issue of how much illegitimate purpose is required to invalidate a statute under the dormant commerce clause is that illegitimate purpose is not a necessary requirement for unconstitutionality under that clause, see Brown-Forman Distillers Corp. v. New York State Liquor Auth., 476 U.S. 573, 578-79 (1986), as it is in equal protection analysis, see Washington v. Davis, 426 U.S. 229, 244-45 (1976). Thus the Court avoids a difficult inquiry into the level of illegitimate purpose by turning to balancing. 
willingness to accept a broader range of purposes, however, will make attempts to prove that regulations were enacted because of illegitimate purposes more difficult in the abortion context than in the area of interstate commerce. A fine line distinguishes expressing a preference for childbirth from intending to create substantial obstacles to pre-viability abortions. ${ }^{104}$

The two standards are also similar in requiring an inquiry into the effects of a statute, even if the statute has a legitimate purpose. The effects prong of dormant Commerce Clause analysis is embodied in the second tier of review. In both, factors such as increased costs and delays, even if incidental, may prove to be undue burdens. ${ }^{105}$ But the effects prong of the dormant Commerce Clause and abortion undue burden analyses are notably different in two respects: in abortion undue burden analysis, as noted earlier, there is no balancing and no examination of alternative regulations. The absence of balancing in the undue burden standard lessens the protection against unnecessary but not undue burdens as well as against unjustified burdens. ${ }^{106}$ In addition, the lack of an examination of alternatives makes the purpose inquiry of the undue burden standard more difficult, since examination of alternative approaches is useful as a means of flushing out illegitimate purposes. The fact that a legislature chose to enact more burdensome regulations over equally effective alternatives suggests that its intention was to hinder, and not to inform, the abortion decision. The Court explicitly uses its examination of alternatives to perform this flushing-out function in the dormant Commerce Clause area. ${ }^{107}$

One final difference between the two approaches deserves notice. Dormant Commerce Clause analysis rests on issues of intergovernmental relations and economic policy, whereas the abortion undue burden standard seeks to accommodate fundamental concerns of personal autonomy and potential life. As a result, a comparison between the two might seem inapposite. However, the impact of this difference in underlying concerns is not clear. The Court is notably unwilling to overturn economic regulations, ${ }^{108}$ yet it is more willing to act in regard to the dormant Commerce Clause because Congress has unlimited power to overrule dormant

104. See Field, supra note 44, at 15; see also Casey, 112 S. Ct. at 2877 (Scalia, J., concurring in the judgment in part and dissenting in part) ("Any regulation ... that is intended to advance ... . the State's 'substantial' interest in protecting unborn life will be 'calculated [to] hinder' a decision to have an abortion." (emphasis omitted)).

105. See Casey, 112 S. Ct. at 2818-20 (joint opinion); Kassel, 450 U.S. at 674; Raymond Motor Transp. v. Rice, 434 U.S. 429, 438-39, 439 n.14 (1978); Bibb v. Navajo Freight Lines, 359 U.S. 520, 524-28 (1959).

106. See supra notes $51-53$ and accompanying text.

107. See Maine v. Taylor, 477 U.S. 131, 138 (1986); Hughes v. Oklahoma, 441 U.S. 322,336 (1979).

108. See, e.g., Williamson v. Lee Optical Co., 348 U.S. 483, 488-91 (1955) (holding that the Court will not strike down economic regulations simply because they are unwise or improvident). 
Commerce Clause decisions. ${ }^{109}$ In any event, these differences would seem more likely to affect the Court's response to identified burdens than the methods it uses to identify them. ${ }^{110}$

\section{Dormant Commerce Clause Techniques and Their Application to Abortion Undue Burden Analysis}

In its dormant Commerce Clause analysis the Court uses certain methods to flush out illegitimate purpose and to calculate the burdens that a regulation imposes. Several of these methods, namely the per se rule against facial discrimination, the surrogacy test, and the cumulative effects principle, can be incorporated into the abortion undue burden standard. The following sections describe these three methods and discuss how they could be applied in the abortion context.

1. The Per Se Rule Against Facial Discrimination. - One of the central techniques employed in dormant Commerce Clause analysis is a virtual per se rule against facial discrimination. Any regulation that on its face imposes greater burdens on out-of-state residents than on in-state residents is almost always struck down as unconstitutional. ${ }^{111}$ The per se rule is useful as an evidentiary device; the presence of discrimination on the face of a regulation is a reliable indication that it was enacted to serve a discriminatory purpose. ${ }^{112}$ This rule relieves the Court of the difficult task of assigning a discriminatory purpose to the entire legislature on the basis of remarks made by particular legislators. If discrimination is evident in the language of a regulation, then the legislature that enacted these words can be said to have intended to discriminate without the Court having to "psychoanalyze [the] legislators." 113 Since the per se rule serves to flush out the discriminatory purpose that led to a regula-

109. See Quill Corp. v. North Dakota ex rel. Heitkamp, 112 S. Ct. 1904, 1916 (1992).

110. Moreover, the three methods taken from dormant Commerce Clause analysisthe per se rule, the surrogacy test and the cumulative effects principle-are present in the Court's individual rights jurisprudence, although in a less easily extrapolated form. See, e.g., United States v. O'Brien, 391 U.S. 367, 383-84 (1968) (importance of facial evidence of purpose); United States v. Carolene Prods., 304 U.S. 144, 152-53 n.4 (1938) (concern with minorities' ability to affect political processes); Ward v. Rock Against Racism, 491 U.S. 781, 801 (1989) (need to measure cumulative effects).

111. See Hughes, 441 U.S. at 337 (1979) ("Such facial discrimination by itself may be a fatal defect . . . . At a minimum such facial discrimination invokes the strictest scrutiny ....").

112. See Regan, supra note 90 , at 1135 . In addition, the Court has explicitly defined economic protectionism as extending to discriminatory means as well as discriminatory purposes. See City of Philadelphia v. New Jersey, 437 U.S. 617, 626-27 (1978) ("[T] he evil of protectionism can reside in legislative means as well as legislative ends."). Thus a state cannot defeat the rule against facial discrimination simply by demonstrating that a legitimate purpose motivated a regulation's enactment.

113. McGowan v. Maryland, 366 U.S. 420, 466 (1961) (Frankfurter, J., concurring). The possibility of avoiding attributing unacknowledged purposes to legislators explains the popularity of facial evidence in other instances of motive review. See O'Brien, 391 U.S. at 383-84. 
tion's enactment, the Court usually will strike down a regulation in its entirety if the state does not meet its justificatory burden, rather than determine whether the discriminatory provision is severable. ${ }^{114}$

The rule is not absolute, however. A statute that is facially discriminatory is subjected to "the strictest scrutiny." 115 A state must demonstrate that its statute is worthwhile and motivated by a legitimate purpose and that non-discriminatory alternatives are unavailable. The Court has rarely accepted such arguments, but the possibility means that facial discrimination is not absolutely prohibited. ${ }^{116}$

The Court has applied the per se rule against facial discrimination quite broadly. ${ }^{117}$ The obvious cases involve laws that clearly forbid interstate commerce in an item, ${ }^{118}$ limit the ability of out-of-state companies to enter an in-state market, ${ }^{119}$ or require economic operations to be performed in-state. ${ }^{120}$ But the Court has also applied the per se rule to invalidate laws where facial discrimination was less clear, such as regulations preventing only some interstate firms from entering a local market, ${ }^{121}$ or imposing restrictions on commerce originating outside of a state subdivi-

114. But see Wyoming v. Oklahoma, 112 S. Ct. 789, 802-04 (1992) and Sporhase v. Nebraska ex rel. Douglas, 458 U.S. 941, 960 (1982) for two instances where the Court was willing to consider severability.

115. Hughes, 441 U.S. at 337.

116. For an instance when the Court did accept this argument, see Maine v. Taylor, 477 U.S. 131 (1986). For commentators' reactions to the per se rule, see Eule, supra note 97, at 461-63 (opposing the per se rule); Regan, supra note 90, at 1134-36 (supporting the virtual per se rule).

117. The broad application of the per se rule appears to deviate from the Court's usual principle of construing statutes so as to avoid constitutional violations where possible. See Edward J. DeBartolo Corp. v. Florida Gulf Coast Bldg. \& Constr. Trades Council, 485 U.S. 568, 575 (1988); Ashwander v. TVA, 297 U.S. 288, 346 (1936). The Court's willingness to forego its usual restraint can be explained by the fact that the per se rule is used to flush out illegitimate purpose, rather than to identify illegitimate effects. Deferential constructions of statutes can ensure that illegitimate effects are avoided, but cannot ensure that illegitimate motivations are prevented. In addition, the Court has indicated that there are limits to the ability of judges to construe statutory language so as to preserve constitutionality. One such limit is that judges cannot offer statutory interpretations that ignore the clear language of a statute. See, e.g., Virginia v. American Booksellers Ass'n, 484 U.S. 383, 397 (1988) (principle only applies where statute is "readily susceptible" "to a construction that would make it constitutional) (quoting Erznoznik v. City of Jacksonville, 422 U.S. 205 (1975)).

118. See Taylor, 477 U.S. at 131; Hughes, 441 U.S. at 337-38; City of Philadelphia v. New Jersey, 437 U.S. 617, 626-27 (1978).

119. See Lewis v. BT Investment Managers, Inc., 447 U.S. 27, 44 (1980); H.P. Hood \& Sons v. Du Mond, 336 U.S. 525, 531 (1949).

120. See Pike v. Bruce Church, Inc., 397 U.S. 137, 145 (1970). There are suggestions that the Court may consider statutory exemptions which benefit local industries to be a form of facial discrimination, although it has also supported its conclusions in such cases with second-tier balancing. See, e.g., Kassel v. Consolidated Freightways Corp., 450 U.S. 662, 676-77 (1981) (using balancing to strike down law that limited truck lengths, despite presence of exception for major in-state industries).

121. See Lewis, 447 U.S. at 39-42. 
sion. ${ }^{122}$ Similarly, the Court has invalidated regulations that contain retaliatory clauses, even though these clauses are not inherently discriminatory since they may serve to exempt a complying state from non-discriminatory burdens it would otherwise face. ${ }^{123}$

The virtual per se rule against facial discrimination is equally applicable to the abortion context, where the inquiry also involves determining whether an illegitimate purpose exists. Recent abortion decisions, including Casey, have demonstrated that the Court is uncomfortable with evaluating legislative motivation in this area. ${ }^{124}$ Use of a per se rule would enable the Court to give substance to the purpose prong of the undue burden standard without having to impute unconstitutional motives to legislators. The lack of an even-handedness requirement under abortion undue burden analysis does not defeat the applicability of the per se rule; indeed, this difference could be said to make the rule even more necessary since the lack of an even-handedness requirement renders the inquiry into legislative purpose more difficult. ${ }^{125}$

The first step in extrapolating the per se rule is determining the form the rule should take in the abortion context. The fact that states may express a preference for childbirth precludes a per se rule against regulations that facially single out abortion for special treatment, such as regulations that impose waiting periods for abortions but not for other surgical procedures. Instead, the appropriate form of a per se rule in the abortion context is a rule against regulations that facially impose substantial obstacles to pre-viability abortions or facially seek to hinder access to abortions. A regulation would trigger the per se rule only if it facially hindered access to abortion in a large fraction of the cases where it was relevant. In Casey the Court held that abortion regulations need not be invalid in all circumstances to be struck down on a facial challenge; it is sufficient that in "a large fraction of the cases in which [the regulation] is relevant, it will operate as a substantial obstacle on a woman's choice to undergo an abortion." ${ }^{26}$ The Court would be able to draw on judicially

122. See C \& A Carbone, Inc. v. Town of Clarkstown, 114 S. Ct. 1677, 1682-83 (1994); Fort Granuit Sanitary Landfill v. Michigan Dep't of Natural Resources, 112 S. Ct. 2019, 2023-26 (1992).

123. Retaliatory clauses remove barriers to the importation of one state's products into another provided the second state does the same. See Sporhase v. Nebraska ex rel. Douglas, 458 U.S. 941, 958 (1982); Smith, supra note 91, at 1240-41. The Court has indicated that some reciprocity agreements may be constitutional. See Great Atl. \& Pac. Tea Co. v. Cottrell, 424 U.S. 366, 378 (1975) (voluntary reciprocity agreement conferring mutual benefits is not per se violation of the Commerce Clause).

124. See Planned Parenthood v. Casey, 112 S. Ct. 2791, 2832-33 (1992) (joint opinion); Ohio v. Akron Ctr. for Reprod. Health (Akron II), 497 U.S. 502, 520 (1990).

125. See supra text accompanying note 104.

126. Casey, 112 S. Ct. at 2829-30 (majority opinion). Justices O'Connor and Souter subsequently reaffirmed this position. See Planned Parenthood v. Casey, 114 S. Ct. 909, 910 \& n.2 (1994) (Souter, J., denying stay of mandate); Fargo Women's Health Org. v. Schafer, 113 S. Ct. 1668, 1669 (1993) (O'Connor, J., concurring in denial of stay). But see Ada v. Guam Soc'y of Obstetricians \& Gynecologists, 113 S. Ct. 633, 633-34 (1992) (Scalia, 
noticeable facts as well as regulatory language in determining that a regulation violates the per se rule. The use of the large fraction threshold and judicially cognizable facts accord with the Court's broad application of the per se rule in the dormant Commerce Clause area. ${ }^{127}$ As is the case under dormant Commerce Clause analysis, the Court should not sever provisions that violate the per se rule, since the rule is used to identify an illegitimate purpose behind the enactment of the statute as a whole.

There are two additional differences in the form of the rule in the abortion context. First, because an undue burden on pre-viability abortions is unconstitutional, a state may not justify a statute that violates the per se rule by claiming that no alternatives are available, as is possible in dormant Commerce Clause review. Rather, the state must prove that the legislation is motivated by a legitimate purpose and will not in fact impose an undue burden on pre-viability abortions, despite its facial appearance. Secondly, since there is no balancing in abortion undue burden analysis the state need not prove that the statute is worthwhile, even though the absence of its postulated benefits likely would be relevant in disproving the state's claim of legitimate purpose. ${ }^{128}$

At first glance, it may be difficult to see the need for a per se rule against statutes that facially impose substantial obstacles, given Casey's holding that any regulation that clearly imposes undue burdens on previability abortions is unconstitutional. Thus, for example, Casey clearly invalidates statutes imposing universal bans on abortion. ${ }^{129}$ A review of recent abortion legislation demonstrates that a per se rule might be advantageous in at least five contexts: bans on sex-selection abortions; bans purporting to allow wide exceptions; bans on abortions after a legislatively determined viability point; choice of method requirements; and legislative declarations that life begins at conception. The regulations at is-

J., dissenting from denial of cert) (Casey did not overrule existing facial challenge doctrine that statute must be sustained unless there is no set of circumstances in which it could be constitutionally applied); see also Barnes v. Moore, 970 F.2d 12, 14 (5th Cir.), cert. denied, 113 S. Ct. 656 (1992) (same). The comments by Justices O'Connor and Souter on the import of Casey should be given greater weight since they wrote the joint opinion, whereas Justice Scalia dissented from the adoption of the undue burden standard. For the claim that the large fraction approach is consistent with the Court's general treatment of facial challenges, see Michael C. Dorf, Facial Challenges to State and Federal Statutes, 46 Stan. L. Rev. 235, 272-74 (1994). It is important to note the differences between a facial challenge and the per se rule. A facial challenge is a legal action arguing that it is clear from a statute's language that the statute will operate unconstitutionally. The per se rule, on the other hand, is an evidentiary device that could be used in a facial challenge.

127. See, e.g., Dean Milk Co. v. City of Madison, 340 U.S. 349, 354 (1951) (statute struck down as discriminatory because practical effect is to protect major local industry against interstate competition). For a description of the broad application of the per se rule in the dormant Commerce Clause area, see supra notes 117-123 and accompanying text.

128. See supra text accompanying notes 51-53.

129. See Sojourner T. v. Edwards, 974 F.2d 27, 30 (5th Cir. 1992), cert. denied, 113 S. Ct. 1414 (1993); Jane L. v. Bangerter, 809 F. Supp. 865, 870 (D. Utah 1992). 
sue in Casey included a prohibition on sex-selection abortions that was not challenged. ${ }^{130}$ The per se rule would apply to such a prohibition, because the statute would act as a substantial obstacle for all women seeking an abortion on these grounds. While such a ban might be struck down under Casey in any case, the advantage of applying the per se rule is that it would relieve challengers of the burden of proving that the legislation either was motivated by a purpose of imposing substantial obstacles or that it will impose such obstacles in fact. Instead such unconstitutional purpose or effect is presumed, and the state would bear the burden of proving otherwise.

The per se rule also would strike down abortion bans that allow wide exceptions, such as Puerto Rico's ban on any abortions not necessary to preserve the life or health of the mother. ${ }^{131}$ A Puerto Rican court upheld the ban on the basis of an extremely broad definition of health that includes "the most ample notions of physical, mental and socioemotional well-being." 132 Under the per se rule, however, statutes would be judged according to their actual text. Aspects of socio-emotional well-being, such as economic or education desires, are not usually classified as health concerns. Therefore, the statute would violate the per se rule unless a broad definition of health was actually incorporated into the text of the statute by the legislature. In addition, the statute would need to state explicitly that it is up to the woman, and not her doctor or the state, to determine whether an abortion is necessary for her health. Otherwise the language of the statute would not give women ultimate control of the abortion decision. Although it might appear that there is little difference in practice between having the law struck down or upheld with a broad definition of health, one potential benefit of the former is that as long as the law exists it is possible for the state to force women and doctors to justify abortions. The state also might be able to impose reporting requirements under the law that are costly and threaten confidentiality. Lastly, there is precedential value in not allowing any pre-viability bans on abortions to be judicially upheld.

The per se rule against facially undue burdens would have even more significant effects on another type of abortion ban, namely prohibitions on terminating a pregnancy after a legislatively determined point of viability. Utah has enacted legislation that defines viability at twenty weeks gestational age and prohibits almost all abortions subsequent to that point. ${ }^{133}$ In Casey the Court claimed that, irrespective of when viabil-

130. See $18 \mathrm{~Pa}$. Cons. Stat. Ann. $\S 3204$ (c) (Supp. 1994). For a discussion of this provision in regard to Casey, see Field, supra note 44, at 19-20. Although sex-selection abortions are problematic for many defenders of abortion rights, this category of abortions cannot consistently be distinguished from other abortions while adhering to a principle of women's bodily autonomy.

131. See P.R. Laws Ann. tit. 33, § 4010 (1983).

132. Pueblo v. Najul Bez, 114 P.R. Dec. 493, 495 (1983) (translated from original) (reaffirming Pueblo v. Duarte Mendoza, 109 P.R. Dec. 596, 607-08 (1980)).

133. See Utah Code Ann. 76-7-302 (Supp. 1994). 
ity occurs, it is "the attainment of viability ... [that] continue[s] to serve as the critical fact." 134 At twenty-one weeks gestation, the point at which the Utah ban takes effect, very few fetuses will be viable. ${ }^{135}$ The Utah district court sustained the ban, arguing that twenty-one weeks represented "the time of possible fetal survival." 136 Under the per se rule, however, the ban would be struck down since on its face the ban clearly imposes an undue burden on some pre-viability abortions. ${ }^{137}$ A similar result should obtain in relation to any attempt to ban abortions after a legislatively determined point of viability, unless it was apparent that viability would have been reached in all cases.

A strong argument also can be made that viability testing requirements at any early date violate the per se rule because such tests will substantially increase the cost of an abortion. In Webster the Court upheld a presumption of viability at twenty weeks, despite evidence that tests for viability might increase the costs of abortions by $\$ 125$ to $\$ 250$ or more. ${ }^{138}$ Moreover, the Court acknowledged that "the tests will undoubtedly show in many cases that the fetus is not viable." 139 The fact that the testing requirement would prove unnecessary in most cases, however, demonstrates that it facially imposes a substantial obstacle on many pre-viability abortions. Under the per se rule, the statute would be held unconstitutional unless the state could prove that in fact a substantial obstacle will not be imposed.

134. Planned Parenthood v. Casey, 112 S. Ct. 2791, 2811-12 (1992) (majority opinion). The Court had previously held that the point of viability should not be legislatively defined but instead left to the physician's judgment. See Planned Parenthood v. Danforth, 428 U.S. 52, 64 (1976); see also Colautti v. Franklin, 439 U.S. 379, 388-89 (1979). Danforth's prohibition of legislative definitions of viability remains good law.

135. In Webster, for example, the Supreme Court accepted a lower court's ruling that the earliest point of viability is twenty-three and a half to twenty-four weeks of gestation. See Webster v. Reproductive Health Servs., 492 U.S. 490, 515-16 (1989) (plurality opinion); F. Gary Cunningham et al., Williams Obstetrics 168-69 (19th ed. 1993) (viability generally occurs between 24 and 28 gestational weeks); see also Planned Parenthood v. Casey, 686 F. Supp. 1089, 1121 (1988), injunction clarified by 736 F. Supp. 633 (1990), aff'd in part, rev'd in part, 947 F.2d 682 (1991), aff'd in part, rev'd in part, 112 S. Ct. 2791 (1992) (citing study suggesting 23.5 to 24 weeks as earliest point of viability).

136. Jane L. v. Bangerter, 809 F. Supp. 865,873 (D. Utah 1992) (emphasis added).

137. The district court justified its action on the grounds that no abortions after twenty weeks were currently being performed in Utah. See id. at 873-74. Under the per se rule, however, the focus would be on the language of the statute and not the current situation in Utah. Since most fetuses between twenty-one weeks and twenty-four weeks gestation are not viable, see supra note 135 , the ban facially will operate as a substantial obstacle on a large fraction of the cases where it would be relevant. The district court also claimed that since twenty weeks was sufficient notice for the pregnant woman, the ban did not represent an undue burden "whether the fetus is non-viable or viable after the twenty week period." Bangerter, 809 F. Supp. at 874 . This conclusion is inconsistent with Casey, which reaffirmed that prohibitions on pre-viability abortions are unconstitutional. See Casey, 112 S. Ct. at 2816 (majority opinion).

138. See Webster, 492 U.S. at 514-15 (plurality opinion).

139. Id. at 519 . 
It is necessary to define facially undue burdens broadly in order for the per se rule to apply to viability testing, because it is not obvious that a testing requirement will impose undue burdens on abortion. ${ }^{140}$ The Court's willingness to apply the per se rule broadly in dormant Commerce Clause context lends support to such an approach. ${ }^{141} \mathrm{~A}$ broad application of the per se rule is fair, because a state has the opportunity to demonstrate that it is not actually creating an undue burden. The ability of states to express a preference for childbirth through abortion regulations prevents the per se rule from applying to every abortion restriction that might impose a burden. Nonetheless, the rule could be applied to instances where there is clear evidence that an undue burden would be created without infringing on this ability.

A fourth type of measure that might trigger the per se rule is choice of method requirements, which mandate that a physician use the method which is most likely to preserve the life of the fetus in performing an abortion. In many cases the method most likely to preserve fetal life may increase the risk to the woman. ${ }^{142}$ Some choice of method requirements expressly require that the woman bear a substantial health risk. For example, Utah requires that physicians performing post-viability abortions use the method that, in their best medical judgment, provides the fetus with the best chance of survival unless doing so will cause the woman's death or grave damage to her health. ${ }^{143}$ According to Casey, however, any regulation that imposes a significant health risk on the woman represents an undue burden. ${ }^{144}$ Therefore, any choice of method provision that expressly requires a woman to bear a significant health risk, or that is not limited to apply only where there would be no significant health risk to the woman, would violate the per se rule. ${ }^{145}$

140. In her concurrence, Justice O'Connor claimed the additional cost would be minimal. See id. at 530 (O'Connor, J., concurring).

141. See supra text accompanying notes 117-123.

142. For example, the safest method for second trimester abortions is dilation and evacuation. See Brief Amici Curiae of the ACLU et al. at 9, Thornburgh v. American College of Obstetricians \& Gynecologists, 476 U.S. 747 (1986) (No. 84-495). However, there is no possibility of fetal survival following this procedure since it involves dismembering the fetus. See id. at 7; Cunningham, supra note 135 , at 680 . Other methods of abortion that may offer a greater chance of preserving the fetus, such as prostaglandin instillations, may cause severe gastro-intestinal side effects and involve an additional risk for women with certain medical conditions. See Brief of the ACLU, supra, at 7-8.

143. See Utah Code Ann. 76-7-307 to 308 (Supp. 1994). The Utah statute requires physicians in exercising their best medical judgment to include a wide variety of factors that are relevant to the well-being of the woman. See id. 76-7-304.

144. See Planned Parenthood v. Casey, 112 S. Ct. 2791, 2822 (1992) (majority opinion).

145. Thus, for example, the Utah provision would violate the per se rule since its use of "grave damage" rather than "significant risk" leaves open the possibility that women would be forced to bear a greater health risk than is constitutional. See Utah Code Ann. 76-7-307 to 308 (Supp. 1994). 
Finally, the per se rule would apply to abortion regulations that contain facial evidence of a legislature's desire to prevent abortions, such as regulations declaring that life begins at conception. The preamble of the abortion statute challenged in Webster declared that life begins at fertilization. The Court upheld the preamble, on the grounds that by its terms the preamble did not actually regulate abortion. ${ }^{146}$ However, such a declaration is relevant not only because of its effect on abortion regulations, but also because of the evidence it provides of legislative purpose. ${ }^{147}$ The fact that the legislature included a declaration that life begins at conception in its abortion regulations supports the conclusion that its purpose in enacting the regulations was to hinder access to abortion. Although the state stipulated that the fetus had only those rights consonant with Supreme Court decisions, it may have done so in order to ensure that abortion would be prohibited in Missouri without further legislative enactment if the constitutional protection of abortion were removed. ${ }^{148}$ Thus the per se rule should be applied, and the state forced to prove that its purpose was not in fact to hinder access. Further, the entire statute and not just the preamble should be struck down unless the state meets its justificatory burden, since the preamble provides evidence of the purpose behind the statute as a whole.

It might be argued that the Webster declaration is simply an expression of the state's preference for childbirth. Since Casey explicitly allowed a state to express its preference for childbirth, the per se rule should not apply to such legislative declarations. But a declaration that life begins at conception goes much further than a declaration that the state prefers childbirth to abortion, because the implications of the former are that abortions should be prohibited. Given the difficulty in differentiating a purpose of expressing a preference for childbirth and a purpose of attacking abortion directly, the state should be required to be explicit when it is simply expressing its preference. Otherwise there is a risk that the purpose prong of the undue burden standard will be rendered virtually meaningless, a result which would be inconsistent with the decision to introduce the purpose prong in Casey. ${ }^{149}$

146. See Webster v. Reproductive Health Servs., 492 U.S. 490, 506 (1989) (plurality opinion).

147. Justices Blackmun and Stevens, as well as the lower court opinions in Webster, found that the purpose of the preamble was to restrict access to abortions. See Webster, 492 U.S. at 539 n.1 (Blackmun, J., concurring in part and dissenting in part), at 562-63 (Stevens, J., concurring in part and dissenting in part); Reproductive Health Servs. v. Webster, 851 F.2d 1071, 1074-77 (8th Cir. 1988); Reproductive Health Servs. v. Webster, 662 F. Supp. 407, 423 (W.D. Mo. 1987).

148. See Mo. Ann. Stat. $\S 1.205 .1$ (Vernon Supp. 1994). This purpose of avoiding the need for further enactment has been made more explicitly in legislative declarations by other states. See, e.g., 1991 La. Acts 26 \& (Supp. 1992).

149. See supra text accompanying notes 55-56 and 64. Since Casey held that expressions of a preference for childbirth are not undue burdens, a declaration limited to stating the state's preference for childbirth over abortion would not violate the per se rule. 
2. Surrogacy Test. - Another technique employed in dormant Commerce Clause analysis is the surrogacy test. If facially neutral legislation appears to burden out-of-state interests unduly, the Court will inquire into whether those interests have in-state representatives or "surrogates." The absence of such surrogates triggers closer judicial review, because it indicates that legislators will not face political pressure to minimize these unequal burdens. ${ }^{150}$ Although the Court has not examined the adequacy of in-state interests as representatives of out-of-state interests, it has only found surrogates to exist when both parties are "affect[ed] alike."151 By "affected alike" the Court appears to mean bearing similar financial burdens. ${ }^{152}$ The surrogacy test was not raised for many years but has resurfaced in some recent opinions. ${ }^{153}$ In a 1977 decision striking down restrictions on the length of trucks, the Court stated that the presumptive validity of the state safety judgments is weakened by exemptions for local businesses, since these exemptions "undermine the assumption that the State's own political processes will act as a check on local regulations that unduly burden interstate commerce. ${ }^{n} 154$ The Court again raised the point in 1981, in regard to a ban on nonreturnable plastic milk containers, arguing that "[ $\mathrm{t}]$ he existence of major in-state interests adversely affected by the Act is a powerful safeguard against legislative abuse."155

150. The surrogacy test is thus an instance of the process-based or representationreinforcing approach to judicial review. See Eule, supra note 97, at 437-43; Mark Tushnet, Rethinking the Dormant Commerce Clause, 1979 Wis. L. Rev. 125, 141, 154. See generally John H. Ely, Democracy and Distrust (1980) (describing and justifying a representation-reinforcing approach to judicial review). The test rests on the interestgroup pluralism model of democracy which underlies many process theories of adjudication, in that the test envisions individuals as exerting political pressure to serve their own economic interests and pictures these interests as fully formed before individuals interact in the political sphere. It is important to note, however, that the test is also compatible with a "republican" conception of politics that emphasizes the endogenous character of preferences and the way that these preferences are shaped through political debate. In the republican approach, the surrogacy test serves as a means of protecting against regulations enacted through raw political power. See Sunstein, Naked Preferences, supra note 81 , at $1694-95,1705 \mathrm{nn} .72-73$.

151. South Carolina Highway Dep't v. Barnwell Bros., 303 U.S. 177, 187 (1938).

152. See id. For example, the Court has not viewed in-state consumers as surrogates for out-of-state interests. See Sunstein, Naked Preferences, supra note 81, at 1705 nn.72-73.

153. The surrogacy test is usually traced to a 1938 opinion written by Justice Stone, who argued that "when the regulation is of such a character that its burden falls principally upon those without the state, legislative action is not likely to be subjected to those political restraints which are normally exerted on legislation where it affects adversely some interests within the state." Barnwell, 303 U.S. at 185 n.2.

154. Raymond Motor Transp. v. Rice, 434 U.S. 429, 447 (1978); see also Kassel v. Consolidated Freightways Corp., 450 U.S. 662, 675-79 (1981) (the presence of affected instate interests ensures that the state's political processes will act as a check on unduly burdensome legislation).

155. Minnesota v. Clover Leaf Creamery Co., 449 U.S. 456, 473 n.17 (1981). Further, concern about the lack of political representation led three Justices to dissent from the Court's decision upholding California's requirement that foreign firms with domestic 
The Court has not specified the exact contours of the surrogacy test in the dormant Commerce Clause area. The test's underlying concern with ensuring that unrepresented interests receive fair treatment might suggest it should be given a broad application. Accordingly, any action or inaction that has a substantial effect on out-of-state interests would be subject to dormant Commerce Clause review, or at least to a determination of the adequacy of representation by affected in-state interests. ${ }^{156}$ The Court, however, has never given the surrogacy test such a broad sweep. Rather, it invokes the surrogacy test only in the limited circumstance where statutes are neutral on their face, ostensibly serve an important state interest, yet appear to impose substantially greater burdens on non-residents than on residents. The surrogacy test thus serves as a means of determining if these burdens amount to discriminatory effects and therefore require searching judicial scrutiny. ${ }^{157}$

The triggering conditions of the surrogacy test are also present in regard to abortion regulations aimed at minors. ${ }^{158}$ While minors can express their interests through testifying and lobbying, they are unable to exert political influence directly since they do not vote. They rely on others, "surrogates," to represent their interests politically. In many contexts the parents of minors can play this surrogate role, and the Court has recognized that parents usually will act to further the best interests of their children. ${ }^{159}$ But there are strong reasons to question the effectiveness of parents as political surrogates for their children in regard to abortion legislation. The restrictions imposed on minors' access to abortion

subsidiaries must report their worldwide income. See Barclays Bank Plc. v. Franchise Tax Bd., 114 S. Ct. 2268, 2289 (1994).

156. See Regan, supra note 90 , at 1162-64.

157. If the surrogacy test discovers discriminatory effects, then Hunt would seem to require that the state bear the burden of justifying the legislation. See Hunt v. Washington State Apple Advertising Comm'n, 432 U.S. 333, 353 (1977) ("When [discriminatory effects are] found, the burden falls on the State to justify" the legislation.). But the cases which embody the surrogacy test do not hold that the state bears the justificatory burden if the statute fails the test; rather, they claim only that such failure leads to less judicial deference. See, e.g., Raymond Motor Transp., 434 U.S. at 443 n.18 (deference to state highway regulations is based on the belief that such regulations will affect local interests as well as out-of-state interests, so that the political process will protect against unduly burdensome regulations).

158. The surrogacy test could be used to argue for careful scrutiny of all abortion legislation on the grounds that women bear the burden of abortion regulations and women are significantly underrepresented in state legislatures. See Estrich \& Sullivan, supra note 65 , at 150-55. But this argument would deviate significantly from the use of the surrogacy test in the dormant Commerce Clause arena, where the Court is concerned with the absolute lack, not disproportionate lack, of direct political power. In addition, this argument would require a detailed examination of theories of political process breakdowns that is beyond the scope of this Note. Applying the surrogacy test to minors avoids many of these difficulties, since the problem facing minors is not a barrier to effective use of their political power but rather a lack of direct political power.

159. See, e.g., Parham v. J.R., 442 U.S. 584, 602-03 (1979) ("[P]ages of human experience... teach that parents generally do act in the child's best interests."). 
are requirements of parental consent or notification. In this context, minors and their parents cannot be described as being "affected alike" by the legislation. On the contrary, any parental gain of control over a minor's abortion decision entails a corresponding loss of control for the minor.

The fact that abortion legislation leads to enhanced parental control over minors' decisions does not by itself demonstrate that the interests of minors are not being effectively represented. Many minors are not capable of mature decisionmaking and greatly benefit from having parental input into their decisions. But it is important to note the ways in which a minor's decision to have an abortion differs from other decisions she may face. As the Court has argued, "many parents hold strong views on the subject of abortion" that may not accord with the best interests of their children. ${ }^{160}$ It was this possibility that led the Court to require judicial bypass procedures, a requirement the Court has not imposed in other areas of parent-child relations. ${ }^{161}$ The decision to have an abortion is different from other choices a minor may face because it cannot be postponed until the minor comes of age. ${ }^{162}$ The abortion decision also differs from other choices because of its significance; a denial of the minor's choice to have an abortion may have exceptionally "grave and indelible" consequences on her life. ${ }^{163}$ These consequences include not only the physical and emotional effects of unwanted childbearing, but also the permanent social and economic costs of teen pregnancy. ${ }^{164}$ Lastly, parental control of abortion decisions can be particularly harmful for the children of abusive parents, since notification of a daughter's pregnancy is likely to spark abuse. ${ }^{165}$

160. Bellotti v. Baird (Bellotti II), 443 U.S. 622, 647 (1979); see also Bellotti v. Baird (Bellotti I), 428 U.S. 132, 141 (1976); Planned Parenthood v. Danforth, 428 U.S. 52, 75 (1975). In Minnesota, statistics compiled by the juvenile court indicated that in 68 out of 258 , or 26 percent, of judicial bypass hearings, parental opposition to abortion was the reason given for seeking the bypass. See Joint Appendix at 380-81, Hodgson v. Minnesota, 497 U.S. 417 (1990) (Nos. 88-1125, 88-1309).

161. See supra text àccompanying note 19. For discussions of the Court's approach to children's rights, and the general acceptance of parental control, see Susan G. Mezey, Constitutional Adjudication of Children's Rights Claims in the United States Supreme Court 1953-92, 27 Fam. L.Q. 307, 308-13 (1993).

162. See Bellotii II, 443 U.S. at 642.

163. Id.

164. See id. For example, "one in four teenage mothers drops out of high school and only one in fifty graduates college." Brief of Amici Curiae Center for Population Options et al. at 10, Hodgson, 497 U.S. at 417 (Nos. 88-1125, 22-1309). For additional discussions of the effects of teenage pregnancy, see NARAL, Promoting Reproductive Choices: A New Approach to Reproductive Health 12 (1994) [hereinafter NARAL, Promoting Reproductive Choices]; Jeff Grogger \& Stephen Bronars, The Socioeconomic Consequences of Teenage Childbearing, 25 Fam. Plan. Persp. 156, 160-61 (1993); Laurie S. Zabin et al., When Urban Adolescents Choose Abortion, 21 Fam. Plan. Persp. 248, 250-54 (1989).

165. See Hodgson, 497 U.S. at 451 n.36. 
Judicial bypass procedures can be seen as an attempt to ensure surrogate representation of the minor's interests; ${ }^{166}$ if the judge determines an abortion is in the minor's best interests, or that the minor is mature enough to decide for herself, the judge will represent the minor's interests by ordering that the minor need not fulfill consent or notification requirements. ${ }^{167}$ The problem with this argument is that it conflates political representation of minors' interests with judicial representation. Judicial representation through a bypass procedure comes only after restrictions on minors have been enacted and therefore such representation is unable to voice minors' interests in avoiding onerous requirements, for instance a two-parent notification or consent requirement. ${ }^{168}$ Relying on judicial representation of minors' interests is particularly problematic when restrictions such as clear and convincing proof requirements are imposed on judicial bypass procedures. ${ }^{169}$

The absence of surrogates for minors in the political process suggests, on the surrogacy rationale, that there is a greater risk that restrictions on minors will be unduly burdensome. As a result, the Court should subject such restrictions to a rigorous review more akin to intermediate or strict scrutiny. The Court should examine, in particular, the benefits achieved by minors' restrictions and ensure that in practice minors possess effective access to a judicial bypass. This conclusion differs dramatically from the Court's current approach to the restrictions. Far from subjecting these restrictions to heightened scrutiny, the Court provides less exacting review than it applies in regard to other abortion restrictions. ${ }^{170}$ The Court has based its lower standard of review on the "immaturity, inexperience and lack of judgment" of minors, and the benefits to minors of parental involvement in most cases. ${ }^{171}$ Most recently

166. Studies of the effect of parental consent and notification requirements provide support for this conclusion. These studies indicate that most judicial bypass requests are granted. See id. at 477 (Marshall, J., dissenting); Gary B. Melton \& Anita J. Pliner, Adolescent Abortion: A Psycholegal Analysis, in Adolescent Abortion 1, 25-28 (Gary B. Melton ed., 1986). However, there is also anecdotal evidence of judicial hostility to abortion. See, e.g., Brief of NAACP Legal Defense \& Educ. Fund, Inc. et al., supra note 58, at 27 (reporting Michigan judge's statement that he would only approve an abortion on a judicial bypass "in cases of incest or the rape of a White girl by a Black man").

167. One point that deserves special note is the assumption that all minors' restrictions contain a bypass procedure. Although in general the Court has required such procedures, it has upheld a parental notification statute that did not have such a procedure where the statute was applied to an immature, unemancipated minor. See H.L. v. Matheson, 450 U.S. 398, 413 (1981); Bellotti II, 443 U.S. at 642-48. The Court has explicitly left open the question of whether notification statutes require bypass procedures. See Ohio v. Akron Ctr. for Reprod. Health (Akron II), 497 U.S. 502, 510-11 (1990).

168. For an example of a statute with such a requirement, see Hodgson, 497 U.S. at 424-26 (requiring notification of both parents without a judicial bypass procedure).

169. See Akron II, 497 U.S. at 514-17 (requiring a complicated pleading process and clear and convincing proof of maturity, abuse, or best interests for judicial bypass).

170. See Planned Parenthood v. Casey, 112 S. Ct. 2791, 2832 (joint opinion); Akron II, 497 U.S. at 510-11; Hodgson, 497 U.S. at 444-45; Matheson, 450 U.S. at 413.

171. Hodgson, 497 U.S. at $444-45 \&$ n.31. 
the Court argued that "[i] $\mathrm{t}$ is both rational and fair . . . to conclude that, in most instances, the family will strive to give a lonely or even terrified minor advice that is compassionate and mature."172 The empirical basis of these claims is debatable; for example, studies indicate that compelling parental consultation does not significantly increase parental involvement. ${ }^{173}$ In addition, these arguments do not address the surrogacy test's concern with legislative abuse and are much less powerful in regard to those restrictions requiring consent or notification of both parents or those imposing onerous bypass procedures. Parental support can be given by one parent, and the Court has held that an adequate bypass procedure is essential to protecting the best interests of minors. Thus at a minimum, the rigorous review imposed as a result of the surrogacy test would call these two types of restrictions on minors into question.

3. Cumulative Effects. - A third technique that the Court employs under its dormant Commerce Clause analysis is a cumulative effects principle. Under this principle, the Court takes all of the effects of the legislation into account in calculating the burden imposed, even those effects that the state did not intend or cannot control. The rationale behind the cumulative effects principle is that the true scope and impact of a regulation cannot be correctly measured unless the effects of a regulation are examined as a whole. A similar principle is found in the Court's approach to congressional power under the Commerce Clause. ${ }^{174}$

There are two ways of applying the cumulative effects principle under the dormant Commerce Clause. One inquiry looks at all of the effects of a statute, including unintended or indirect effects, to determine whether a statute is reasonable or overly burdensome. For example, the Court invalidated a state statute taxing mail order sales, arguing that allowing such taxation might indirectly deter investment by mail order firms. ${ }^{175}$ In a similar inquiry into aggregate effects, the Court held that a limit on the length of trains would not yield any safety benefits, because shorter trains meant more train trips. ${ }^{176}$ The second approach places legislation into a national context. The Court takes into account the effects one state's regulations have in other states in assessing whether the regulations are unduly burdensome. Hence it included the fact that Iowa's restriction of truck lengths increased accidents in neighboring

172. Akron II, 497 U.S. at 520.

173. A comparison of Minnesota, which requires consultation, and Wisconsin, which does not, showed a statistically indistinguishable percentage of minor women voluntarily consulted a parent (65.3 percent versus 62.1 percent). See Brief of Amici Curiae Center for Population Options, supra note 164 , at $18 \mathrm{n} .70$.

174. In this context, the principle requires that the Court calculate the interstate effect of all instances of the activity in the nation. See Wickard v. Filburn, 317 U.S. 111, 125-28 (1942).

175. See Quill Corp. v. North Dakota ex rel Heitkamp, 112 S. Ct. 1904, 1915 (1992).

176. See Southern Pac. Co. v. Arizona ex rel. Sullivan, 325 U.S. 761, 775 (1945); see also Kassel v. Consolidated Freightways Corp., 450 U.S. 662, 674-75, 675 n.17 (1981). 
states in its calculation of the safety benefits of the limits. ${ }^{177}$ In tax cases the Court determines whether a state's apportionment formula is burdensome by calculating the effect on a company if the formula were applied by all states. ${ }^{178}$ Finally, the Court measures the burden imposed by one state's legislation in comparison to the regulatory policies of other states. For example, Illinois' requirement of contour mudguards was struck down for unduly burdening commerce because most states allowed-and one state required-straight mudguards. ${ }^{179}$ This inquiry into cumulative effects often accompanies the Court's second-tier balancing of the benefits and burdens of legislation, but nonetheless represents a distinct stage in the analysis. The Court first applies the cumulative effects principle to calculate what the benefits and burdens of the legislation are and then employs balancing to determine whether the legislation is justified. ${ }^{180}$

The cumulative effects principle is equally applicable to abortion regulations. ${ }^{181}$ As in the case of legislation affecting interstate commerce, the Court's concern is to ensure that abortion regulations are not too burdensome in practice. In addition, the full impact of an abortion regulation cannot be determined unless all its effects are calculated. There is also support for a cumulative effects principle in the Casey joint opinion itself, which emphasized that women must retain the "right to make the ultimate decision" concerning abortion. ${ }^{182}$ This focus on ultimate control would seem to require an examination of cumulative effects. Further, the Casey opinion emphasized the need to examine regu-

177. See Kassel, 450 U.S. at $674-75$ \& n.18, 677-78.

178. See Container Corp. v. Franchise Tax Bd., 463 U.S. 159, 169-70 (1983) (describing the "internal consistency" requirement that a formula must not result in taxation of more than 100 percent of the unitary business' income if applied in every jurisdiction); see also Armco Inc. v. Hardesty, 467 U.S. 638, 644-45 (1984) (applying internal consistency test of Container Corp.). The Court does not compare the tax measures in effect in different states. See Tyler Pipe Indus. v. Washington Dep't of Revenue, 483 U.S. 232, 242 (1987).

179. See Bibb v. Navajo Freight Lines, 359 U.S. 520, 526-27 (1959); see also Kassel, 450 U.S. at 671 (Iowa truck length limit "out of step with the laws of all other Midwestern and Western States"); Morgan v. Virginia, 328 U.S. 373, 381-82 (1946) ("cumulative effects" make racial separation on public carriers impracticable).

180. See $B i b b, 359$ U.S. at 526-28 (cumulative effect of regulation as part of "rather massive showing of burden on interstate commerce" from the regulation); Southern Pac., 325 U.S. at 775-76 (cumulative calculation used to determine "total [safety] effect" of regulation, which is then weighed against burden on interstate commerce).

181. On the need to calculate the cumulative effects of abortion regulations, see Ohio v. Akron Ctr. for Reprod. Health (Akron II), 497 U.S. 502, 527 (1990) (Blackmun, J., dissenting); Walter Dellinger \& Gene B. Sperling, Abortion and the Supreme Court: The Retreat from Roe v. Wade, 138 U. Pa. L. Rev. 83, 99-103 (1989); Estrich \& Sullivan, supra note 65 , at 137.

182. Planned Parenthood v, Casey, 112 S. Ct. 2791, 2821 (1992) (joint opinion). 
lations in light of their actual effects, and explicitly required the inclusion of "incidental" effects in undue burden determinations. ${ }^{183}$

The inquiry into indirect and unintended effects can be extrapolated to the abortion context without alteration from its dormant Commerce Clause form. The Court would determine whether the actual effects of a regulation, even if unintended or indirect, created an undue burden. The examination of the husband notification requirement in Casey represents such an analysis. The Court struck down the requirement because it held that the actual, albeit unintended, effect would be to deny access to abortion for many women. ${ }^{184}$ In addition, the Court would examine whether the indirect or unintended effects of an abortion regulation call the reasonableness of the regulation into question. Such an inquiry would be particularly useful in examining statutes that require the consent or notification of both parents before a minor can obtain an abortion. ${ }^{185}$ A two-parent notification and consent requirement often undercuts family structure and communication; it forces divorced parents to apply for a judicial bypass to avoid contacting noncustodial spouses, and minors who might have consulted one parent often will not do so if they must apply for judicial bypass in any case. ${ }^{186}$

Although such an inquiry into the actual effects of a regulation would be consistent with the theoretical framework of the undue burden standard, it would deviate from the application of the standard to most of the provisions at issue in Casey. The Casey opinion held that all abortion regulations should at a minimum be subjected to rationality review, but applied the weak rationality review associated with economic due process, which does not consider the actual effects of regulations. ${ }^{187}$ A rationality review that examines the actual effects of legislation would be more akin to the rationality-with-bite approach the Court has occasionally used where legislation affects liberty interests not amounting to fundamental rights or particular groups which are not specially protected under equal protection analysis. ${ }^{188}$ Rationality-with-bite examines whether the regula-

183. See id. at 2819,2825 . Justice Souter's recent decision holding open the possibility of an as applied challenge to Pennsylvania's abortion regulations provides further evidence of the Court's focus on actual effects. See Planned Parenthood v. Casey, 114 S. Ct. 909, 910 n.3 (1994) (Souter, J., denying stay of mandate).

184. See Casey, $112 \mathrm{~S}$. Ct. at 2826-31 (majority opinion).

185. The Court used an examination of unintended and indirect effects in striking down a two-parent notification statute which lacked a bypass. See Hodgson v. Minnesota, 497 U.S. $417,450-52$ (1990).

186. See id. at $438,440,450-51$.

187. See Casey, 112 S. Ct. at 2824-25 (joint opinion) (citing Williamson v. Lee Optical Co., 348 U.S. 483 (1955), which is an instance of the application of weak rationality review to economic regulations).

188. See Cleburne v. Cleburne Living Ctr., 473 U.S. 432, 442-43 (1985) (mentally retarded); Plyler v. Doe, 457 U.S. 202, 223-24 (1982) (children of illegal aliens); Eisenstadt v. Baird, 405 U.S. 438, 446-47 (1972) (access to contraception for unmarried individuals). For discussion and critical assessment of the rationality-with-bite approach, see Tribe, supra note $48, \S 16-3$ at $1443-46$; Fallon, supra note 47 , at 312-27; Gerald Gunther, The 
tion in fact achieves its stated purpose and also reviews the legitimacy of this purpose. ${ }^{189}$ Several arguments support a shift to employing the rationality-with-bite approach and examining actual effects. Such an approach fits Casey's concern with gauging the effects an abortion regulation has in practice. It would also conform with the Court's analysis of other reproductive rights and family autonomy. ${ }^{190}$ In addition, although rationality-with-bite provides more searching review of regulations, it usually does not involve balancing the burdens and benefits of regulations or examining alternative legislation. ${ }^{191}$

The second form of the cumulative effects principle, where the Court places legislation in a national context, must be adapted to apply to abortion regulations. The interstate effects of abortion regulations may be relevant but are not central to an examination of their constitutionality under the undue burden standard. ${ }^{192}$ But the rationale behind inquiring into the interstate effects in the dormant Commerce Clause context is to determine the total impact of a regulation on the affected parties. Similarly, in order to determine the total impact of an abortion regulation, the Court must assess the impact of the regulation with reference to other abortion regulations enacted by the state. This version of

Supreme Court, 1971 Term-Forward: In Search of Evolving Doctrine on a Changing Court: A Model for a Newer Equal Protection, 86 Harv. L. Rev. 1 (1972).

189. See Cleburne, 473 U.S. at 446-50; Tribe, supra note $48, \S 16-3$ at $1443-46$.

190. See Moore v. City of E. Cleveland, 431 U.S. 494, 498-99 (1977) (personal choice in matters of family living arrangements); Eissenstadt, 405 U.S. at 443 (access to contraceptives).

191. The Court has been notably unclear about the characteristics of its rationalitywith-bite approach, and often has maintained that it is applying regular rationality review. See Cleburne, 473 U.S. at 448-50. It cannot be stated definitively, therefore, that the Court does not engage in balancing or examine alternatives under the rationality-with-bite approach. In some circumstances, such as mental patients' interests in freedom from restraint or the education of children of illegal aliens, the Court has balanced the benefits and burdens of regulations. See Youngberg v. Romeo, 457 U.S. 307, 320-24 (1982); Plyler, 457 U.S. at 218-24; Aleinikoff, supra note 51, at 969-72. But the Court has employed language associated with intermediate scrutiny in these cases. See Plyler, 457 U.S. at 221-24 (emphasizing the importance of access to education and requiring a substantial rather than legitimate state goal). Where the Court simply uses the language of rationality review, it does not engage in balancing. In addition, although under rationality-with-bite the Court may suggest alternative ways of phrasing a classification, this examination of alternatives is used to question the legitimacy of a stated purpose and not as part of a narrow. tailoring requirement. See Clebume, 473 U.S. at 449.

192. Restrictive abortion regulations may create undue burdens in other states. For example they may result in much heavier use of out-of-state abortion providers and thus lead to increased delay in access to abortion in neighboring states. See Brief of Amici Curiae the City of New York et al., Planned Parenthood v. Casey, 112 S. Ct. 2791 (1992) (Nos. 91-744, 91-902). Moreover, the interstate dimension of abortion regulations may be relevant in assessing the constitutionality of some regulations, for example where a state imposed residency requirements for women seeking abortions within its boundaries. See Lea Brilmayer, Interstate Preemption: The Right to Travel, the Right to Life, and the Right to Die, 91 Mich. L. Rev. 873 (1993). These interstate issues raised by abortion regulations are beyond the scope of this Note. 
the cumulative effects principle would require that in reviewing a challenged statute the Court determine the effects of the statute as a whole, not just of each separate provision. In addition, the Court would need to determine the impact of the challenged statute in combination with other already existing restrictions on abortion.

This use of the cumulative effects principle is again not consistent with the application of the undue burden inquiry in Casey. In assessing whether Pennsylvania's abortion regulations created an undue burden the joint opinion analyzed each provision separately. However, the opinion provided no justification for this approach. Moreover, examining the effect of a challenged statute as a whole, and in relation to existing regulations, is consistent with the undue burden standard's underlying concern with ensuring that a regulation does not create a substantial obstacle barring access to abortion, even incidentally. Provisions that individually do not impose undue burdens may combine to create such a substantial obstacle.

$$
* * * *
$$

A comparison of the dormant Commerce Clause two-tiered inquiry and the Casey undue burden standard demonstrates how three methods used in the dormant Commerce Clause context could be incorporated into the undue burden standard. The per se rule of facial invalidity would lead the Court to strike down regulations that facially impose substantial burdens on pre-viability abortions. The surrogacy test would require judges to scrutinize restrictions on minors more carefully to ensure that such restrictions serve the interests of minors. Lastly, the cumulative effects principle would require that judges examine the actual effects of abortion regulation, as well as calculate the total effect of all of the regulation's provisions and of the regulation in conjunction with other restrictions on abortion.

\section{First Amendment Models}

Two First Amendment approaches, the content-neutral, traditional forum analysis applied to speech and the endorsement test of the Establishment Clause, also involve fact-sensitive inquiries into the purpose and effect of a regulation. A comparison of the abortion undue burden standard with these approaches suggests several additional techniques that could be used to construct a more systematic method for determining when undue burdens exist. Content-neutral, traditional forum analysis justifies an explicit focus on the impact of regulations on poor women, while the endorsement test offers a procedure for identifying the purpose of a regulation and an acknowledgement of the coercive power of symbolic effects. This comparison again demonstrates that the abortion undue burden standard is virtually unique in its lack of protection against unnecessary but not undue burdens. 


\section{A. Content-Neutral, Traditional Forum Analysis and the Undue Burden Standard}

1. A Comparison of Content-Neutral, Traditional Forum Analysis and the Abortion Undue Burden Standard. - Content-neutral, traditional forum analysis is used to determine the constitutionality of statutes that regulate the time, place, and manner of speech. The Court applies a different level of review to such statutes depending on where the speech occurs. ${ }^{193}$ The standard of review is strongest for speech occurring in "quintessential public forums," which "by long tradition or by government fiat have been devoted to assembly and debate." 194 In such contexts, the Court distinguishes between content-neutral and content-based regulations. Content-neutral regulations are subject to intermediate review and must be "narrowly tailored to serve a significant government interest, and leave open ample alternative channels of communication." 195 Content-based regulations, on the other hand, receive strict scrutiny; they must be necessary to serve a compelling state interest. ${ }^{196}$ Regulations limiting speech in contexts the Court has identified as "non-public" or "limited" public forums need only be reasonable in light of the purposes of the property and not represent attempts to suppress a particular viewpoint. ${ }^{197}$

The Court's approach to content-neutral regulations of speech in a traditional forum is useful for developing the abortion undue burden standard. ${ }^{198}$ The content-neutral, traditional forum analysis is notably similar to the undue burden standard in at least three significant respects. Both are fact-sensitive standards that hinge on a case-by-case examination of the record. The fact-sensitivity of the content-neutral, traditional forum analysis results from the Court's concern with the "actual, physical characteristics and uses of the property," as demonstrated in its

193. See Cornelius v. NAACP Legal Defense \& Educ. Fund, Inc., 473 U.S. 788, 800 (1985) (stating that "the extent to which the Government can control access depends on the nature of the relevant forum"); Perry Educ. Ass'n v. Perry Local Educ. Ass'n, 460 U.S. $37,45-46$ (1983) (delineating separate categories of forum which correspond to varying levels of free speech protection).

194. Perry, 460 U.S. at 45.

195. Id.

196. See Boos v. Barry, 485 U.S. 312, 321 (1988).

197. See United States v. Kokinda, 497 U.S. 720, 727, 730 (1990) (plurality opinion); Cormelius, 473 U.S. at 806 ; Perry, 460 U.S. at $45-46,49$. Limited public forums are places that the government has opened as areas of expressive activity, while non-public forums are public properties that have not been so opened. See id. at 45-46. In recent cases, however, the Court essentially has collapsed the limited public forum into a non-public forum by holding that the contours of a limited public forum are set by the government's intent when it opened up the property. See Cornelius, 473 U.S. at 804-06; see also Robert C. Post, Between Governance and Management: The History and Theory of the Public Forum, 34 UCLA L. Rev. 1713, 1745-58 (1987).

198. The non-public forum inquiry is not comparable because rationality review is not applied to abortion regulations until the Court has determined that the regulations do not impose an undue burden. Content-based, traditional forum analysis also is inapplicable because abortion regulations need not serve a compelling government interest. 
detailed examination of the property at issue. ${ }^{199}$ Additionally, both standards contain purpose and effect prongs and hold that a regulation may be struck down if it violates either prong. In the abortion context, a regulation cannot have the purpose or effect of creating a substantial obstacle to access to pre-viability abortions. ${ }^{200}$ In content-neutral, traditional forum analysis the purpose prong is represented by the content-neutral and significant government interest provisos, and the effects prong by the narrow tailoring and alternative channels requirements.

Most importantly, content-neutral, traditional forum analysis shares the undue burden standard's concern for ensuring that regulations do not create substantial obstacles to the exercise of a constitutionally protected right. In the former analysis, this concern is captured by the inquiry into whether the regulation preserves "ample alternative channels" for speech. Since the content-neutral, traditional forum analysis states that a regulation must be struck down if sufficient alternatives do not exist, it appears to define certain obstacles as unconstitutional regardless of resulting benefits. ${ }^{201}$

Yet there are also three notable differences between the two standards that limit the extent to which content-neutral, traditional forum analysis can supply a methodology for the undue burden standard. A regulation must be even-handed for content-neutral, traditional forum analysis to apply; any regulation that distinguishes according to subject matter or viewpoint is judged on the content-based standard. In contrast, states are explicitly allowed to express their preference for childbirth in abortion regulations. This requirement of content-neutrality does not make a comparison to the undue burden standard inappropriate. For although abortion regulations need not be neutral, they cannot seek to create substantial obstacles in the path of a woman seeking to obtain a pre-viability abortion. Therefore, both standards deem certain purposes illegitimate. The absence of a neutrality requirement under the abortion undue burden standard does make the search for illegitimate purpose more difficult in the abortion context than in the free speech area, since

199. See Lee v. International Soc'y for Krishna Consciousness, 112 S. Ct. 2709, 2716 (1992) (Kennedy, J., concurring); see also Tribe, supra note 48, § 12-2 at 792-94, § 12-24 at 990-91. For particularly striking examples of this detailed examination, compare the discussion of sidewalks in Kokinda, 497 U.S. at 727-29 (plurality opinion) (holding that post office sidewalk is not a public forum) with that in United States v. Grace, 461 U.S. 171, 178-80 (1983) (holding that sidewalk surrounding the Supreme Court is a public forum).

200. See supra text accompanying notes 32-37.

201. Although on its face the content-neutral, traditional forum analysis appears to require that a regulation be struck down when alternatives do not exist, in practice the Court has been willing to uphold some such regulations if the type of expression at issue is considered to be of "lower value." See, e.g., Barnes v. Glen Theatre, 111 S. Ct. 2456 (1991) (availability of alternative channels not considered in review of ban on public nudity). 
a purpose of expressing a preference for childbirth may be hard to distinguish from a purpose of preventing abortions. ${ }^{202}$

The second and third differences are that content-neutral, traditional forum analysis requires a significant government interest while the undue burden standard demands only a legitimate and reasonable government interest, and further that the former involves balancing whereas the latter does not. ${ }^{203}$ The absence of significant interest and balancing requirements in the undue burden standard underscores again the standard's lack of protection against unnecessary but not undue burdens and unjustified burdens on abortion access. The significant interest requirement in practice serves as a shield against unnecessary burdens because it forces the government to demonstrate that the regulation actually advances a worthwhile interest. ${ }^{204}$ Under content-neutral, traditional forum analysis balancing is often achieved through the narrow tailoring requirement, which is akin to the search for non-discriminatory alternatives under the dormant Commerce Clause. As part of the content-neutral, traditional forum standard, narrow tailoring does not necessitate employing the least restrictive means available; rather, a regulation is considered narrowly tailored provided it does not burden substantially more speech than is necessary. ${ }^{205}$ In several recent cases the Court has used the effectiveness of the current regulation as the baseline against which "necessary" is defined and has struck down statutes for violating the narrow tailoring requirement only where an alternative would accomplish the state's purposes equally effectively. ${ }^{206}$ Nevertheless, even this weak interpretation of narrow tailoring offers greater protection against unnecessary burdens than is provided under the Casey undue burden standard. Under Casey, if a regulation does not impose an undue burden on pre-

202. This difference between the abortion undue burden standard and traditional forum analysis parallels a difference between the undue burden standard and dormant Commerce Clause analysis, in that the latter embodies a neutrality requirement in its insistence on even-handed regulations. See supra text accompanying note 104.

203. See Schneider v. State, 308 U.S. 147, 161 (1939); Sullivan, Supreme Court, supra note 47 , at 61; supra text accompanying notes 51-53.

204. See United States v. Grace, 461 U.S. 171, 182-83 (1983); Schaumburg v. Citizens for a Better Env't, 444 U.S. 620, 636-39 (1980); Geoffrey R. Stone, Content-Neutral Restrictions, 54 U. Chi. L. Rev. 46, 52 \& n.27 (1987). It should be noted that the Court has employed the content-neutral, traditional forum standard very deferentially in some cases, for example by not inquiring into whether the government's interest is in fact significant. See id. at 48-54. This deference is closely connected to the Court's recent restriction of the scope of traditional public forums. See supra note 197 and accompanying text. In addition, the Court has rarely held that an asserted government interest is not significant, but instead has used the significant interest requirement to force more narrow tailoring. See Lee v. International Soc'y for Krishna Consciousness, 112 S. Ct. 2709, 2713-14 (1992) (O'Connor, J., concurring); Grace, 461 U.S. at 182.

205. See Ward v. Rock Against Racism, 491 U.S. 781, 799-800 (1989); Frisby v. Schultz, 487 U.S. 474, 485 (1988); Clark v. Community for Creative Non-Violence, 468 U.S. 288, 297 (1984).

206. See Ward, 491 U.S. at 801-02; United States v. Albertini, 472 U.S. 675, 689 (1985); Clark, 468 U.S. at 297-99. 
viability abortions the court only applies a very weak version of rationality review. ${ }^{207}$ As a result, the existence of a less burdensome, equally effective alternative is irrelevant to determining the constitutionality of an abortion regulation. ${ }^{208}$

\section{The Alternative Means Inquiry and the Impact of Regulations on the} Poor. - This comparison has indicated that the abortion undue burden standard and the content-neutral, traditional forum analysis are both factsensitive approaches that contain purpose and effect prongs and inquire into the extent of the burden imposed by regulations. Since the significant interest and narrow tailoring requirements are not found in the undue burden standard, the techniques employed to apply these requirements cannot be extrapolated to the abortion context. ${ }^{209}$ The techniques used to establish whether ample alternative channels exist, however, are useful in determining whether an undue burden is created. While the Court has never developed a specific technique for gauging the adequacy of alternative channels, it has traditionally displayed a particular concern with the impact a regulation would have on people with few resources-or, in the words of an early opinion, with the impact on "the poorly financed causes of little people." 210 A similar concern is found in regard to the effect voting regulations will have on free expression. ${ }^{211}$ Recent traditional forum cases do not express as strong a concern with the impact of regulations on people with few resources. ${ }^{212}$ These cases,

207. See Planned Parenthood v. Casey, 112 S. Ct. 2791, 2824-25 (1992) (joint opinion); supra notes 48 and 187 and accompanying text.

208. For a similar conclusion reached from comparing the abortion undue burden standard with the dormant Commerce Clause analysis, see supra text accompanying notes 106-107.

209. It should be mentioned, however, that the cumulative effects principle is used in content-neutral, traditional forum analysis as a means of determining whether a significant government interest exists. In this context, the principle holds that the government should look at the benefits of a regulation in general, rather than in relation to one group. See Ward, 491 U.S. at 801; Clark, 468 U.S. at 296-97; Heffron v. International Soc'y for Krishna Consciousness, 452 U.S. 640, 652-53 (1981). See supra text accompanying notes 181-192 for a discussion of the applicability of the cumulative effects principle in the abortion context.

210. Martin v. City of Struthers, 319 U.S. 141, 146 (1943).

211. See Anderson v. Celebrezze, 460 U.S. 780, 793-94 (1983) (striking down early filing requirement for independent candidates); Brown v. Socialist Workers "74 Campaign Comm., 459 U.S. 87, 98 (1982) (holding that a state cannot compel a party to make disclosures that will subject its members to threats, harassment, or reprisals). A similar concern is raised in Bullock v. Carter, 405 U.S. 134 (1972), but primarily in regard to the right to vote and not free expression. See id. at 143-45; see also Stone, supra note 204, at 84-86 (discussing approaches used where content-neutral restriction has a disparate impact on different groups).

212. The Court has upheld bans on sleeping in parks, on signs attached to utility poles, and on placing unstamped material in private mailboxes, all of which impacted particularly strongly on groups with few resources. See Clark, 468 U.S. at 313 n.14 (Marshall, J., dissenting) (parks); City Council v. Taxpayers for Vincent, 466 U.S. 789, 819-20 (1984) (Brennan, J., dissenting) (utility poles); United States Postal Serv. v. Council of Greenburgh Civic Ass'n, 453 U.S. 114, 143-44 (1981) (Marshall, J., dissenting) 
however, appear to reflect an attempt by the Court to narrow the scope of the traditional public forum, not a lack of interest in the effects of regulations on the poor. ${ }^{213}$

In addition, even if the Court is less concerned with the effect on groups with few resources, the belief that special attention should be given to the effect of regulations on the poor continues to be voiced. In a 1992 case striking down a ban on leafletting in airports, Justice Kennedy wrote:

The effect of a rule of law distinguishing between sales and distribution would be to close the marketplace of ideas to less affluent organizations and speakers, leaving speech as the preserve of those who are able to fund themselves. One of the primary purposes of the public forum is to provide persons who lack access to more sophisticated media the opportunity to speak. A prohibition on sales forecloses that opportunity for the very persons who need it most. 214

Thus it appears that the alternative channels inquiry continues to involve a focus on the impact of a regulation on people with few resources.

A similar focus should characterize the inquiry into undue burdens in the abortion context. ${ }^{215}$ One of the key factors affecting the availability of abortion is the cost of the procedure. A focus on the impact regulations have on poor women is vital because only twelve states allow public funding for abortion in most instances. ${ }^{216}$ Focusing on the impact on poor women is also important because poor women have significantly higher rates of unintended pregnancies, in part because they are more likely to experience contraceptive failure. ${ }^{217}$

(mailboxes). In upholding the sign ban Justice Stevens argued that "[a]lthough the Court has shown special solicitude for forms of expression that are much less expensive than feasible alternatives and hence may be important to a large section of the citizenry, ... this solicitude has practical boundaries." Taxpayers for Vincent, 466 U.S. at 812 n.30 (citations omitted).

213. See Taxpayers for Vincent, 466 U.S. at 814 (utility poles are not traditional public forums); Greenburgh, 453 U.S. at 128 (letterboxes are not public forums). But see Clark, 468 U.S. at 293 (applying traditional public forum analysis to parks).

214. Lee v. International Soc'y for Krishna Consciousness, 112 S. Ct. 2711, 2723 (1992) (Kennedy, J., concurring).

215. For similar suggestions that abortion regulations should be assessed in terms of their effect on poor women, see Dellinger \& Sperling, supra note 181, at 102-03; Estrich \& Sullivan, supra note 65 , at $134-35,154$.

216. See NARAL, Who Decides? A State-by-State Review of Abortion Rights 145 (1993) [hereinafter NARAL, Who Decides?]. These numbers may increase in light of the recent congressional amendment providing Medicaid funding for abortions where the pregnancy resulted from rape or incest. See 1994 Hyde Amendment, Pub. L. No. 103-112, $\$ 510,107$ Stat. 1113 (1993). The Clinton Administration interpreted this statute as requiring that all states provide such funding, and this interpretation has been upheld by several courts. See, e.g., Little Rock Planning Serv. v. Dalton, No. LR-C-93-803, 1994 WL 386796 (E.D. Ark. July 25, 1994).

217. See Brief of Amici Curiae NAACP Legal Defense \& Educ. Fund, Inc. et al., supra note 58 , at $17-18$. 
Such a focus accords with the undue burden standard as enunciated in Casey, but not with the application of the standard to the Pennsylvania regulations. The Casey joint opinion explicitly acknowledged the relevance of an investigation into the expense caused by a regulation, noting that "at some point increased cost could become a substantial obstacle." 218 The opinion also insisted that regulations should be judged by their impact on women for whom they are a restriction. ${ }^{219}$ These comments would suggest that a review of abortion regulations should contain an examination of the effect of cost increases caused by the regulations on poor women, since such increases are most likely to be a restriction for poor women. But the joint opinion failed to provide any focused analysis of the Pennsylvania regulations on poor women. The opinion upheld the recordkeeping requirements, maintaining that "[a]t most they might increase the cost of abortions by a slight amount," 220 without indicating whether this cost was also slight for women with few resources. Indeed, the opinion appeared to discount the prohibitive effect that cost increases might have on some women. For example, it distinguished the husband notification requirement from the other restrictions, on the grounds that this requirement "does not merely make abortions a little more ... . expensive to obtain; for many women, it will impose a substantial obstacle."221

Explicitly adapting the perspective of poor women as the standpoint from which costs are evaluated would ensure that a focus on the effect of abortion regulations on women with few resources is included in the undue burden standard. The Court would determine whether increased costs are slight or substantial explicitly from this perspective. If the Court found that a regulation would result in a significant increase in the cost of an abortion, the regulation would be struck down for imposing an undue burden. Thus, there would be no need for any additional inquiry into whether the increase actually operated as a substantial obstacle to abortion access. ${ }^{222}$ It would be presumed that a significant increase in the cost of abortion was a substantial obstacle to abortion access for poor women.

A focus on the impact of abortion regulations on poor women would be particularly useful in challenging hospitalization requirements, mandated tests to determine fetal size or viability, and waiting periods. Such hospitalization and testing requirements can double the cost of abor-

218. Planned Parenthood v. Casey, 112 S. Ct. 2791, 2833 (1992) (joint opinion).

219. See id. at 2829 (majority opinion).

220. Id. at 2833 (joint opinion).

221. Id. at 2829 (majority opinion).

222. The Casey opinion engaged in this second investigation in its review of waiting periods. See id. at 2825-26 (joint opinion) (finding that a waiting period imposes a particular burden on poor and rural women cannot be equated with finding that it is a substantial obstacle). 
tions. ${ }^{223}$ Waiting periods dramatically increase costs by forcing women who must travel to reach an abortion provider either to make two trips or to stay overnight near the provider. They also increase costs by requiring women to lose an additional day of work or to pay twice for childcare. ${ }^{224}$ Data on the effect of a twenty-four hour waiting period in Mississippi show that during the first six months of the waiting period's implementation there has been an eleven to thirteen percent decline in the overall number of abortions obtained, and a twenty-nine percent decline among women with less than twelve years of education. ${ }^{225}$

In addition, this focus could potentially provide a basis on which to challenge the current distinction between abortion regulations and abortion funding. ${ }^{226}$ The Court has long held that the government may refuse to pay for abortions under Medicaid, even if they are medically necessary and even if the government provides coverage for childbirth. In Webster, the Court upheld a ban on the use of public hospitals and employees for elective abortions. ${ }^{227}$ The Court's acceptance of such prohibitions rests on the belief that the government is not responsible for the condition of poverty which makes abortion services less accessible to some women absent subsidization. ${ }^{228}$ In contrast, when the government regulates abortion it creates obstacles to abortion access that would not have existed absent the government's actions. The Court has also argued that since a denial of funding does not create unconstitutional obstacles, the government is entitled to use its resources to foster its preference for childbirth. ${ }^{229}$

Arguably, these rationales become less convincing under the undue burden standard, particularly if the undue burden standard is held to

223. See City of Akron v. Akron Ctr. for Reprod. Health (Akron I), 462 U.S. 416, 434-35 (1983); see also Webster v. Reproductive Health Servs., 492 U.S. 490, 514 (1989) (testing requirement may add $\$ 150-\$ 200$ to the cost of an abortion).

224. See discussion of Pennsylvania's waiting period, infra notes 290-92 and accompanying text.

225. See Record at 129-31, Northland Family Planning Clinic v. Engler, No. 94-40089 (E.D. Mich. 1994) (evidence reported by Stanley K. Henshaw, Deputy Director of Research at the Alan Guttmacher Institute). Additional evidence gathered by the Alan Guttmacher Institute indicates that this decline is not attributable to women changing their minds about obtaining an abortion during the waiting period. See id. at 134 .

226. A discussion of the general principles underlying the funding-regulation or benefits-burdens divide is beyond the scope of this Note. As a result, the following discussion simply focuses on the possibility of a change in the approach to abortion funding. For more general discussion of the topic, see Tribe, supra note $48, \S 11-5$ at 781-84; Kathleen M. Sullivan, Unconstitutional Conditions, 102 Harv. L. Rev. 1413 (1989) [hereinafter Sullivan, Unconstitutional Conditions].

227. See Webster, 492 U.S. at 507-511 (plurality opinion).

228. See Harris v. McRae, 448 U.S. 297 (1980) (government need not fund even medically necessary abortions); Maher v. Roe, 432 U.S. 464 (1977) (government need not fund therapeutic abortions even if it funds childbirth).

229. See Webster, 492 U.S. at 511 (citing Poelker v. Doe, 432 U.S. 519, 521 (1977)); Maher, 432 U.S. at 474 . The Court's approach to the issue of abortion funding conforms to its analysis of conditions attached to welfare funding in general. 
require a careful examination of the effects of abortion on poor women. The strict categorical divide between funding and regulation is inconsistent with the Court's move away from formal rules in the abortion arena. ${ }^{230}$ As evidenced by its adoption of the undue burden standard, the Court is now willing to accept some regulatory burdens on abortion access and has eschewed the clear structure of strict scrutiny analysis for a more malleable measuring approach. ${ }^{231}$ Moreover, according to Casey a legitimate purpose cannot vindicate regulations that impose substantial obstacles to access to abortion. The fact that the government's purpose in denying funding is to express and foster its preference for childbirth would be irrelevant if the funding denial imposed such obstacles. On this interpretation of the abortion undue burden standard, the central issue becomes whether these prohibitions create substantial obstacles to abortion access in practice.

Once attention is focused on the actual effects of bans on the use of public funding and public facilities for abortion, their burdensome character becomes more apparent. The actual effect of funding denials and new financial burdens caused by abortion regulations is identical: impeding a poor woman's access to abortion. Studies have indicated that the cutoff in Medicaid abortion funding may have resulted in a twenty percent decline in the number of Medicaid eligible women obtaining abortions and in delays averaging two to three weeks for some women.292 Further, there are several arguments that can be made as to why these bans impose burdens beyond those that poor women would face absent any government funding scheme, simply as a result of their poverty. For example, the availability of funds to cover the expenses of pregnancy and childbirth, but not for abortion, may exert coercive pressure on poor women to choose childbirth. ${ }^{233}$ Public hospitals and clinics may represent the only health facilities in many areas. ${ }^{234}$ In addition, funding for other family planning services may have led women to establish relationships

230. For a discussion of Casey as representing a move away from formal rules, see Sullivan, Supreme Court, supra note 47 , at 34 . Sullivan has argued elsewhere that a move away from a categorical approach might lead to reconsideration of some funding decisions. See Kathleen M. Sullivan, Post-Liberal Judging: The Roles of Categorization and Balancing, 63 U. Colo. L. Rev. 293, 312-17 (1992); Sullivan, Unconstitutional Conditions, supra note 226 , at $1500-05$.

231. See supra text accompanying notes $42-46$.

232. See Stanley K. Henshaw \& Lynn S. Wallisch, The Medicaid Cutoff and Abortion Services for the Poor, 16 Fam. Plan. Persp. 170, 180 (1984) (delays averaging two to three weeks); James Trussell et al., The Impact of Restricting Medicaid Financing for Abortion, 12 Fam. Plan. Persp. 120, 129-30 (1980) (approximately one-fifth of pregnant, Medicaideligible women have unwanted children as a result of the Medicaid cutoff).

233. See Harris v. McRae, 448 U.S. 297, 330, 333-34 (1980) (Brennan, J., dissenting).

234. See Brief of Amicus Curiae National Ass'n of Public Hosp. at 7-8, Webster v. Reproductive Health Servs., 492 U.S. 490 (1989) (No. 88-605); see also Rachel B. Gold, Alan Guttmacher Institute, Abortion and Women's Health: A Turning Point for America? 54 (1990). Moreover, private hospitals may not admit uninsured women who are at risk of complications even when these women have the funds necessary to cover the abortion 
with physicians at public clinics. ${ }^{235}$ Prohibitions on the use of public facilities or public employees for abortions are particularly burdensome in those states that require hospitalization for second trimester abortions, ${ }^{236}$ or where the state has defined public facilities and employees so broadly as to apply to institutions with minimal public connections. ${ }^{237}$

The Court's funding-regulation dichotomy in regard to abortion has been criticized as inconsistent with the Court's jurisprudence regarding conditions attached to government funding, and with the strict scrutiny applied to abortion regulations under Roe. ${ }^{238}$ Although the undue burden standard also leads to a challenge to this dichotomy, the frequent distinction between expressions of legislative preference and undue burdens in the Casey opinion indicates strongly that the Court will be unwilling to reconsider its abortion funding decisions. ${ }^{239}$

This examination of the content-neutral, traditional forum analysis of the First Amendment suggests that the Court should adopt the perspective of women with few resources in calculating the impact of an abortion regulation. If, using this perspective, the Court determines that a regulation substantially or even significantly increases the cost of an abortion, the regulation should be struck down as imposing an undue burden.

procedure, for fear that these women will not be able to pay for additional services. See Brief of National Ass'n of Public Hosps., supra, at 8-9.

235. See Brief of National Ass'n of Public Hosp., supra note 234, at 4-6; Brief of Amicus Curiae the National Family Planning and Reproductive Health Ass'n at 13-14, Webster (No. 88-605).

236. The Court sustained second-trimester hospitalization requirements in Planned Parenthood v. Ashcroft, 462 U.S. 476 (1983).

237. An example of such minimal connection is found in the ban on the use of public facilities at issue in Webster, which included any institution that leased land from the state or a state subdivision in the definition of public facility. See Webster, 492 U.S. at 540 n.1 (Blackmun, J., dissenting).

238. For examples of these criticisms, see Michael J. Perry, Why the Supreme Court Was Plainly Wrong in the Hyde Amendment Case: A Brief Comment on Harris v. McRae, 32 Stan. L. Rev. 1113 (1980) (abortion funding doctrine inconsistent with Roe); Sullivan, Unconstitutional Conditions, supra note 226, at 1440 (abortion funding doctrine inconsistent with other unconstitutional conditions cases); Laurence $H$. Tribe, The Abortion Funding Conundrum: Inalienable Rights, Affirmative Duties, and the Dilemma of Dependence, 99 Harv. L. Rev. 330 (1985) (government has affirmative duty to fund certain individual rights, including the right to choose abortion). Sullivan also attacks other unconstitutional conditions decisions and offers an alternative analysis that focuses on the systemic effects that benefit conditions have on the distribution of power between rights-holders and the government. See Sullivan, Unconstitutional Conditions, supra note 226, at 1489-1505.

239. See Planned Parenthood v. Casey, 112 S. Ct. 2791, 2818-20 (1992) (joint opinion). It also notable that Justice Stevens, who would have struck down most of the Pennsylvania regulations at issue in Casey, reaffirmed the state's right to express its preference for childbirth through its funding policies. See id. at 2840-41 (Stevens, J., concurring in part and dissenting in part). 


\section{B. The Endorsement Test and the Abortion Undue Burden Standard}

1. The Endorsement Test and a Comparison to the Abortion Undue Burden Standard. - An additional First Amendment doctrine that can supply useful methods for applying the abortion undue burden standard is the "endorsement test," one of the analyses applied to determine whether a government regulation violates the Establishment Clause. Under the endorsement test, regulations are struck down if the "government's actual purpose is to endorse or disapprove of religion" or its effect "in fact conveys a message of endorsement or disapproval."240 The Court has variously defined endorsement as promoting religion or sending a "message that a particular religious belief is favored or preferred."241 Justice O'Connor initially offered the endorsement test in her concurrence in Lynch $v$. Donelly ${ }^{242}$ as a reformulation of the three-prong test set forth in Lemon v. Kurtzman. ${ }^{243}$ Although not adopted by a majority of the Court, the endorsement test nonetheless has figured prominently in many recent Establishment Clause cases. ${ }^{244}$

The endorsement test bears several similarities to the abortion undue burden standard. The endorsement test, like the undue burden standard, involves "close factual analysis" rather than reference to fixed rules. ${ }^{245}$ The parallel phrasing of the two standards illustrates their similarities: undue burden analysis inquires into whether a regulation "has the purpose or effect of placing a substantial obstacle in the path of a woman seeking [a pre-viability abortion]," 246 while the endorsement test examines "whether the challenged governmental practice either has the

240. Lynch v. Donnelly, 465 U.S. 668, 690 (1984) (O'Connor, J., concurring); see also County of Allegheny v. ACLU, 492 U.S. 573, 589-94 (1989) (discussing the various definitions of endorsement used by the Court); Edwards v. Aguillard, 482 U.S. 578, 585 (1987) (quoting Justice O'Connor's concurrence in Lynch); Wallace v. Jaffree, 472 U.S. 38, 56 (1985) (same). For discussions of the endorsement test, see William P. Marshall, "We Know It When We See It" The Supreme Court and Establishment, 59 S. Cal. L. Rev. 495 (1986); Steven D. Smith, Symbols, Perceptions and Doctrinal Illusions: Establishment Neutrality and the "No Endorsement" Test, 86 Mich. L. Rev. 266 (1987).

241. Wallace, 472 U.S. at 70 (O'Connor, J., concurring); accord Allegheny, 492 U.S. at 593.

242. 465 U.S. at $612-13$.

243. 403 U.S. 602 (1971). The endorsement test represents a narrowing of Lemon. Under the endorsement test, a regulation may be upheld even if its primary effect is to advance or inhibit religion, provided it does not endorse religion. A non-secular motivation or government entanglement that does not represent endorsement of religion in purpose or effect is acceptable. See Lynch, 465 U.S. at 691-92 (O'Connor, J., concurring). Under Lemon, a principal effect of advancing or inhibiting religion leads to invalidation, as does excessive entanglement, even if this entanglement does not amount to endorsement. See Lemon, 403 U.S. at 612-13.

244. See Lee v. Weisman, 112 S. Ct. 2649, 2664 (1992) (Blackmun, J., concurring); id. at 2671-72 (Souter, J., concurring); Allegheny, 492 U.S. at 592-97; Wallace, 472 U.S. at 72.

245. See Allegheny, 492 U.S. at 606-08, 614 n.60, 629-30; Lynch, 465 U.S. at 694 (O'Connor, J., concurring) (every government practice must be judged in its specific circumstances).

246. Planned Parenthood v. Casey, 112 S. Ct. 2791, 2820 (1992) (joint opinion). 
purpose or effect of 'endorsing' religion."247 The endorsement test also shares the undue burden standard's concern with effects that pass a certain threshold, in that the test only condemns entanglements that amount to endorsement and not entanglements per se, and examines the overall effect of legislation. ${ }^{248}$

The differences between the endorsement test and the undue burden standard do not prevent a useful comparison of the two. As was the case with the dormant Commerce Clause and content-neutral, traditional forum speech regulations, the endorsement test requires a neutral, evenhanded purpose while in the abortion context the government is allowed not only to express its preference for childbirth, but also to impose regulations designed to achieve this preference. Yet this difference in acceptable purposes is not as great as it might at first appear. Although Casey allows states to pursue a preference for childbirth, it forbids legislation motivated by a desire to hinder abortion; likewise, under the endorsement test, states are allowed to acknowledge the role of religion or provide benefits to religions but cannot do so if their actions are motivated by a desire to endorse religion.

A more significant difference concerns the way they approach the burdens imposed by a regulation. The endorsement test is concerned with the quality of a legislation's effect, not its quantity or magnitude; the extent of a law's endorsement of religion is irrelevant. The extent or quantity of burdens, however, is central to the undue burden standard. In addition, under the endorsement test the effects of legislation or government actions are measured from the perspective of an average individual, ${ }^{249}$ whereas Casey requires assessing burdens from the position of those women for whom they are a restriction. ${ }^{250}$

2. The Inquiry into Purpose and Symbolic Effects. - This difference in the two standards' approaches to regulatory burdens indicates that the endorsement test can provide little guidance on how to calculate the extent of the burden imposed by an abortion regulation. Nonetheless, the endorsement test can make important contributions to an undue burden

247. Allegheny, 492 U.S. at 592.

248. See Lynch, 465 U.S. at 691-92 (O'Connor, J., concurring). Although the Lemon inquiry shares this fact-sensitive character and the focus on purpose and effect, it differs significantly from the abortion undue burden standard. Lemon bars government entanglement with religion and ignores the indirect and remote effects of legislation, while the undue burden standard allows entanglement unless it creates substantial obstacles and includes incidental effects. Hence the endorsement test is a more appropriate comparison. Compare Lemon, 403 U.S. 602, 612-13 (1971) (holding that to survive an Establishment Clause challenge a statute's primary or principal effect must not advance religion and the statute must not create excessive entanglement with religion) with Casey, $112 \mathrm{~S}$. Ct. at 2819 (joint opinion) (holding that a state is allowed to create a structural mechanism to express its preference for childbirth unless the effects of this mechanism, both intended and incidental, serve to create a substantial obstacle to abortion access).

249. See Allegheny, 492 U.S. at 620 (plurality opinion) (reasonable observer); Wallace v. Jaffree, 472 U.S. 38, 76 (1985) (O'Connor, J., concurring) (objective observer).

250. See supra text accompanying note 36 . 
standard methodology, specifically techniques for identifying illegitimate purpose and a recognition of the burdensome character of symbolic effects. Attempts to apply the purpose prong of the endorsement test have faced two problems. The first concerns the extent to which a purpose to endorse religion must be present for the endorsement test to be violated, and the second the method by which the Court determines legislative purpose. The Justices who have applied the endorsement test have held that a purpose to endorse exists only if the goal of endorsing religion was the government's primary motivation in enacting the law.251 Although these Justices will invalidate laws motivated by this goal even though these laws also serve secular purposes, they appear to require proof that an identified illegitimate purpose was strong enough to cause the challenged act's adoption independent of the legitimate purpose. In other areas of jurisprudence the Court often takes the opposite approach; once a plaintiff has demonstrated the presence of an illegitimate purpose, the defendant must prove that the legitimate purpose was independently motivating. ${ }^{252}$ A possible explanation for this increased deference is that the legislation can be struck down on the basis of its effects alone in the Establishment Clause area, whereas in other areas an illegitimate purpose is required. ${ }^{253}$

The Court's approach in determining legislative motivation is also deferential.254 Yet there are limits to this deference; the Court does not accept the government's account of its motivation if it concludes this account is insincere and "a sham." ${ }^{255}$ The Court gives emphasis to the words of the statute but it also will look beyond the statute's text to ensure that a stated purpose is genuine. ${ }^{256}$ The Court has questioned the genuineness of a stated purpose on the basis of legislative history, the

251. See Edwards v. Aguillard, 482 U.S. 578, 585 (1987); id. at 599 (Powell, J., concurring); Wallace, 472 U.S. at 56, 59; id. at 75 (O'Connor, J., concurring).

252. See Price Waterhouse v. Hopkins, 490 U.S. 228, 242-44 (1989) (plurality opinion); Village of Arlington Heights v. Metropolitan Hous. Corp., 429 U.S. 252, 270, n.21 (1977); Mount Healthy Sch. Dist. Bd. of Educ. v. Doyle, 429 U.S. 274, 287 (1977). But see Church of the Lukumi Babalu Aye, Inc. v. City of Hialeah, 113 S. Ct. 2217, 2230 (1993) (suggesting purpose inquiry under Free Exercise and Establishment Clause is parallel to that used in equal protection cases).

253. See Wallace, 472 U.S. at 75 (O'Connor, J., concurring) (The "inquiry into the effect of an enactment would help decide those close cases where the validity of an expressed purpose is in doubt."). In contrast, illegitimate purpose is required under equal protection analysis. See Washington v. Davis, 426 U.S. 229, 239-42 (1976) (purpose to discriminate required for equal protection violation).

254. See Edwards, 482 U.S. at 586-87; Wallace, 472 U.S. at 74-75 (O'Connor, J., concurring).

255. See Edwards, 482 U.S. at 587; Wallace, 472 U.S. at 75 (O'Connor, J., concurring). See also Stone v. Graham, 449 U.S. 39, 41 (1980) (avowed purpose not sufficient to satisfy Establishment Clause inquiry).

256. See Edwards, 482 U.S. at 594-95. Although the words of a statute are given great weight, there is no per se rule against statutes which facially foster religious practices since the Court has held that efforts to accommodate religion do not violate the Establishment Clause. See Zorach v. Clausen, 343 U.S. 306, 313-14 (1952). 
social and historical context of the legislation, and the events leading up to enactment. ${ }^{257}$ Remarks by legislators are considered relevant, although a finding of illegitimate purpose on this basis alone is uncommon. ${ }^{258}$ The Court also has looked to previously existing laws for evidence of the legislature's intent in enacting a new law on the same topic. For example, the Court relied on the fact that a previous statute established daily moments of silence in public schools for prayer when it struck down a new law creating a moment of silence for meditation and voluntary prayer. 259

The endorsement test's approach to both of these problems in identifying purpose is well suited to the undue burden inquiry. The purpose prong of the undue burden inquiry is particularly unclear. ${ }^{260}$ The Casey opinion upheld Pennsylvania's recordkeeping requirements on the grounds that "it cannot be said that the requirements serve no purpose other than to make abortions more difficult."261 This would suggest that any legitimate purpose, however inconsequential to the regulation's enactment, can satisfy the purpose inquiry. But such an approach would render the purpose inquiry essentially meaningless, and thus is inconsistent with the decision to introduce the purpose prong in Casey. Adopting the requirement that a regulation's challengers must prove illegitimate purpose to be independently motivating would accord with the Court's apparent desire to treat legislative purpose in the abortion context deferentially, while giving some substance to the purpose inquiry. There is a strong argument for using the endorsement test methodology for determining motivation as well, because of the difficulty of distinguishing between regulations that aim to create undue burdens and those that simply seek to express a preference for childbirth. An examination of legislative history and the context in which the regulations are enacted can help ensure that the former illegitimate purpose is exposed. ${ }^{262}$ The device of comparison to existing regulations is particularly helpful. Since many abortion regulations, such as reporting requirements, are passed ostensibly to serve health goals, a comparison to existing reporting regulations can demonstrate whether this health motive is sincere and whether it was the reason for enactment.

A second aspect of the endorsement test analysis is its focus on symbolic effects and psychological pressure. In advocating the endorsement

257. See Edwards, 482 U.S. at 592-95; Wallace, 472 U.S. at 58, 75-77 (O'Connor, J., concurring).

258. But see Wallace, 472 U.S. at 58, 75-77 (O'Connor, J., concurring) (noting reluctance to base illegitimate purpose on legislative comments but arguing that in this instance such comments are particularly illuminative).

259. See id. at 58-60.

260. See supra text accompanying notes $55-56$.

261. Planned Parenthood v. Casey, 112 S. Ct. 2791, 2833 (1992) (joint opinion).

262. Such an examination would complement the per se rule of facial invalidity, extrapolated from dormant Commerce Clause analysis. See supra text accompanying notes $124-149$. 
test, Justice O'Connor has argued that the danger of endorsement is its symbolic effect; it "sends a message to nonadherents that they are outsiders, not full members of the political community . . ."263 Moreover, the Court has noted the coercive effect of psychological pressure and argued that " $[t]$ his pressure, though subtle and indirect, can be as real as any overt compulsion." ${ }^{264}$ Although the Court has been particularly concerned about the psychological pressure in schools, it has noted that such pressure may be relevant in other contexts as well. ${ }^{265}$

This recognition of the importance of symbolic effects and psychological pressure is also applicable to the abortion undue burden inquiry. The approach to psychological pressure and symbolic effects in Casey was remarkably inconsistent; the joint opinion appeared to weigh heavily the effects of psychological pressure in invalidating the husband notification requirement, yet made no reference to symbolic effects or psychological pressure in its examination of the other provisions. It is true that, unlike the endorsement test, the undue burden inquiry specifically permits symbolic endorsement, since states are allowed to express their preference for childbirth. But such expressions are prohibited if they amount to undue burdens. Hence the state's ability to foster childbirth does not foreclose an inquiry into the symbolic effects of legislation and the psychological pressure such symbolic expressions may cause. ${ }^{266}$ Given Casey's emphasis on actual effects, the Court should examine the symbolic effects and psychological pressure imposed by regulations as well as their more overt impact. Indeed, in earlier cases the Court has acknowledged the coercive power of psychological pressure in the abortion context..267

Inclusion of symbolic effects is particularly relevant in assessing whether "informed consent" requirements create an undue burden. In Akron I, the state-mandated physician lecture included the statement that "the unborn child is a human life from the moment of conception." 268 This statement arguably fulfills Casey's requirement that the information provided to women must be "truthful [and] nonmisleading" despite its normative character, yet it clearly has the potential of exerting tremen-

263. Lynch v. Donnelly, 465 U.S. 668, 688 (1984) (O'Connor, J., concurring). This concern with the symbolic effects of legislation runs throughout the Court's references to the endorsement test, and underlies its insistence that coercion is not required for an Establishment Clause violation. See County of Allegheny v. ACLU, 492 U.S. 573, 627-28 (1989) (O'Connor, J., concurring); School Dist. v. Ball, 473 U.S. 373, 397 (1985).

264. Lee v. Weisman, 112 S. Ct. 2649, 2658-59 (1992).

265. See id. at 2658 (citing Allegheny for the example of the erection of permanent religious symbols in government buildings).

266. As Justice Stevens noted in his Casey dissent, it does not follow from allowing the state to express a preference for childbirth that the state can express this preference in ways that coerce the woman's decision. See Planned Parenthood v. Casey, 112 S. Ct. 2791, 2840-41 (1992) (Stevens, J., concurring in part and dissenting in part).

267. See Thornburgh v. American College of Obstetricians \& Gynecologists, 476 U.S. 747, 762-64 (1986); City of Akron v. Akron,Ctr. for Reprod. Health (Akron I), 462 U.S. $416,443-45$ (1983).

268. Akron I, 462 U.S. at 444; see also Field, supra note 44, at 15. 
dous psychological pressure. Such pressure, particularly on minors, could easily be as great as the pressure to participate in school prayers; in the abortion context, however, psychological pressure has far more indelible consequences. Nor is the danger of psychological intimidation restricted to normative statements. Rather, as Justice Blackmun noted, other more objective forms of information such as "graphic literature or films detailing the performance of an abortion operation" also may inflict psychological pressure, ${ }^{269}$ as may depictions of the developing fetus.

The Court should include all of the symbolic effects of abortion regulations in its calculations, not only those effects that may exert direct psychological pressure. For instance, a woman confronted with waiting periods and "informed consent" requirements when she is seeking an abortion receives the symbolic message that the government and society do not trust her decisions. Although this symbolic message may be too diffuse to exert psychological pressure directly on her decision, it may undercut her confidence in her choices and make her more accepting of the state's preferences. ${ }^{270}$ The cumulative effects principle provides an argument for including such symbolic effects in undue burden calculations, even if they do not create an undue burden on their own. ${ }^{271}$

The endorsement test thus provides two techniques that can be used in applying the abortion undue burden standard. First, the Court should examine the legislative history of abortion regulations, the context in which they were enacted, and the character of previously existing abortion regulations in order to determine whether the regulations were enacted in order to hinder access to abortion. This review would be deferential, and the regulations would be struck down only if the Court determined that this illegitimate purpose was strong enough to motivate enactment of the regulations independent of the legitimate purposes also served. But the review would not be so deferential that the mere recitation of a legitimate purpose would satisfy the purpose prong of the undue burden standard. Second, the Court would include symbolic effects in its calculation of the impact of abortion regulations. If a regulation exerted substantial direct psychological pressure on a woman's decision, it would be struck down as imposing an undue burden even though it did not impose more overt obstacles on access to abortion. In addition, symbolic effects creating indirect psychological pressure would be included in undue burden calculations. part).

269. Casey, 112 S. Ct. at 2851 n.7 (Blackmun, J., concurring in part and dissenting in

270. This symbolic effect also may undercut women's equality in society because of the way it revives "outmoded and unacceptable assumptions about the decisionmaking capacity of women." Casey, 112 S. Ct. at 2842 (Stevens, J., concurring in part and dissenting in part).

271. See supra text accompanying notes 181-192. 


\section{A Re-examination of CASEY}

This examination of the two-tiered dormant Commerce Clause inquiry, the content-neutral, traditional forum analysis, and the endorsement test has suggested several techniques that could be used to construct a new methodology for the undue burden standard. These techniques are the per se rule of facial invalidity, the surrogacy test, the cumulative effects principle, an emphasis on the impact of regulations on poor women, a general investigation of motivating purpose, and an inclusion of symbolic effects. The new undue burden methodology would involve a two-step analysis, first inquiring into the purpose behind an abortion regulation and second calculating its effects. Re-examining some of the Pennsylvania abortion regulations challenged in Casey will illustrate this more rigorous undue burden methodology. It will also demonstrate how the Casey framework could be altered to provide protection against unnecessary but not undue burdens on access to abortion.

\section{A. The Contours of a New Undue Burden Methodology}

The new undue burden methodology would consist of a two-step analysis. The first step would be an inquiry into the purpose behind enactment of an abortion regulation to determine whether this purpose was to create a substantial obstacle to abortion access. This purpose inquiry would involve application of the per se rule against facially undue burdens and a more general investigation into the motivation behind a regulation. Under the per se rule of facial invalidity, any abortion regulation that facially displayed an intention to impose substantial obstacles or to hinder access to pre-viability abortions would be invalidated unless the state could prove that the regulation was motivated by a legitimate purpose and would not create undue burdens. Since the per se rule is an evidentiary device used to flush out an illegitimate purpose, the entire regulation would be invalidated when the per se rule is violated, even if this violation is limited to a specific provision. As part of the general investigation into motivating purpose, the Court would examine the legislative history of an abortion regulation, the context in which it was enacted, and the regulations that existed prior to its enactment. If the Court determined that the illegitimate purpose of imposing substantial obstacles to abortion access independently caused the regulation's enactment, it would invalidate the regulation.

The purpose prong inquiry belongs first for reasons of judicial economy. The two methods suggested for the purpose prong-the per se rule against facially undue burdens and the general investigation of motivating purpose-are both limited inquiries that do not involve factual analysis. Since failure to satisfy the purpose prong results in invalidation of the regulations, initial application of these methods may forestall detailed examination of the record. For similar reasons, the per se rule of facial invalidity should be employed before the general investigation into legislative purpose. The per se rule involves only an examination of legislative 
text, whereas the general investigation extends to an examination of legislative history and context.

If the regulation survives application of the per se rule and the general investigation of motivating purpose, then the Court would proceed to the second step of analysis-calculating the effects of the regulation. The methods for this calculation are the surrogacy test, the cumulative effects principle, the emphasis on the effects of regulations on poor women, and the inclusion of symbolic effects. These methods can be seen as creating a four-stage inquiry into a regulation's effects. First, the Court would examine the actual effects of each separate provision, including incidental and symbolic effects, to establish whether the regulation created a substantial obstacle to abortion access. If a regulation imposed increased costs, whether these costs are slight or substantial would be determined based on their impact on poor women. Second, the actual effects of each provision would be examined under the rationality-with-bite approach to determine whether the regulation in fact advances a legitimate state purpose. ${ }^{272}$ In the third stage, the Court would examine the cumulative effects of all of the provisions and of the new regulation in combination with existing regulations to determine if the total impact of the regulation created an undue burden. Lastly, any restriction on minors would be subjected to careful examination under the surrogacy test, to establish whether the restriction would serve minors' interests and whether it would provide an adequate judicial bypass.

\section{B. The New Undue Burden Methodology and Casey}

The contours of this new undue burden methodology become more apparent through an application of the methodology to the Pennsylvania abortion regulations challenged in Casey. These regulations mandated anti-abortion lectures by physicians, twenty-four hour waiting periods, husband notification, informed parental consent, and extensive recordkeeping and contained a narrow exception for medical emergencies. ${ }^{273}$

1. The Purpose Inquiry. - The analysis of the regulations under the new methodology begins with an inquiry into their motivating purpose, achieved by applying the per se rule against facial invalidity and the general investigation of legislative motivation. This inquiry suggests that the Court might well have concluded that the purpose motivating the Pennsylvania regulations was a desire to hinder women's access to abortion rather than to inform their choice. However, as discussed below, the confusion created by the Court's decision in Webster prevents invalidation of the Pennsylvania regulations on the basis of purpose alone.

272. This second stage does not include comparing a regulation to alternative measures, because such a comparison would exceed the confines of rationality review, even the rationality-with-bite variety. An examination of alternatives cannot be incorporated into the undue burden methodology without altering the outline of the undue burden standard as enunciated in Casey. See infra part IV.C.

273. See supra text accompanying notes 26-27. 
Most of the Pennsylvania requirements do not trigger the per se rule, since it is not clear from their language that they will create substantial obstacles to abortion access. The one exception is the medical emergency provision. According to the Court, any regulation that prevents an abortion where there is a significant risk to the woman's health is an undue burden. ${ }^{274}$ The Pennsylvania medical emergency provision by its terms imposes a narrower exception; there must be a serious risk of substantial and irreversible impairment to a major bodily function for the provision to apply. ${ }^{275}$ As a result, this provision appears to facially impose an undue burden. In order to avoid this conclusion it is necessary to construe the terms of the provision quite broadly, as covering all significant health risks whether or not a risk of substantial and irreversible impairment exists. Indeed, the Supreme Court took such an approach in sustaining the provision, as did the Third Circuit. ${ }^{276}$ Under the new methodology, however, such a broad interpretation would be prohibited by the per se rule, on the grounds that broad interpretations ignore important evidence of legislative purpose. Applying the per se rule, the state should bear the burden of proving that the regulation was motivated by a legitimate purpose and not that of seeking to protect fetal life even at the cost of some significant risk to the woman. In addition, the state would have to show that the exception does not create an undue burden.

Pennsylvania might argue that the purpose behind the exception was purely to protect women against health risks that they might face as a result of the other abortion regulations. But the statutory language defeats this defense, for if Pennsylvania's goal were simply to protect women's health, it would have adopted a broader exception. The legislative history also indicates that in fact the legislature believed the life of the fetus to be more important than the health of the woman. ${ }^{277} \mathrm{~A}$ more viable defense for the state would be to claim that its legislature was unsure of the level of health risks that would be constitutional, given the indications in Webster that Roe might soon be overruled. This defense is supported by the substantial discussion of the import of Webster in the legislative history. ${ }^{278}$ It should be noted, however, that this defense would only apply to Pennsylvania, and not to states that enacted abortion regulations after Casey resolved the confusion created by Webster. ${ }^{279}$

274. See Casey, 112 S. Ct. at 2822 (majority opinion).

275. See 18 Pa. Cons. Stat. Ann. § 3203 (Supp. 1994).

276. See Casey, 112 S. Ct. at 2822 (majority opinion) (adopting the statutory interpretation offered by the Third Circuit).

277. See Pa. Legis. Journal-House 20 (daily ed. Oct. 24, 1989) (sponsor of regulations arguing that "when it is health against the life of the baby, then it comes down in favor of the unborn baby").

278. See id. at 19-25.

279. Since Casey several states have adopted the statutory language of the Pennsylvania medical exception rather than the broader interpretation of that language by the Supreme Court, and without explicit acknowledgement that the Casey interpretation applies. See, e.g., Mich. Comp. Laws Ann. § 333.17015(d) (West Supp. 1994); Utah Code 
Pennsylvania could then argue that the provision would not create an undue burden through its effects, because all medical conditions which create a significant risk to the woman's health impose the requisite risk of substantial and irreversible harm in some circumstances. Therefore, all of these conditions would trigger the medical emergency provision. ${ }^{280}$

Since the per se rule is not clearly violated, the analysis should proceed to the general investigation of motivating purpose. This investigation focuses on legislative history, the social and historical context of the regulations, and previously existing laws, although reliance on legislative comments alone is discouraged. In this instance, the legislative history displays a longstanding attempt to impose restrictions on abortion, with the re-enactment of provisions that had previously been held unconstitutional. Pennsylvania's 1982 abortion regulations also contained "informed consent" and waiting period requirements, and these requirements were struck down. ${ }^{281}$ The fact that Pennsylvania had re-enacted provisions deemed unconstitutional suggests that the motivation behind the regulations was to impose substantial obstacles to abortion access and not simply to encourage childbirth. Again, however, the confusion created by Webster may forestall the conclusion that Pennsylvania was motivated by an illegitimate purpose. The legislative history demonstrates that several legislators believed the 1982 regulations would be held constitutional after Webster. ${ }^{282}$ There is also evidence in the legislative history that the legislature desired to deter abortions. For example, the sponsor of the 1989 legislation repeatedly expressed his view that abortion was killing and should be prohibited. ${ }^{283}$ But it is unclear whether the legislature hoped to deter abortions by hindering access or by encouraging women to choose childbirth. The existence of such ambiguous evidence of purpose in the legislative history, combined with the deferential attitude of the inquiry into legislative purpose, prevents the conclusion that the illegitimate purpose of imposing undue burdens on access to abortion was an independent motivation for the regulations.

2. The Calculation of Effects. - The next step under the new methodology is to calculate the effect of abortion regulations in order to deter-

Ann. \$76-7-301(2) (Supp. 1994). These provisions appear to violate the per se rule and would cause the invalidation of the statute as a whole under the new methodology.

280. See Casey, 112 S. Ct. at 2822 (majority opinion).

281. See Thornburgh v. American College of Obstetricians \& Gynecologists, 476 U.S. 747 (1986); Planned Parenthood v. Casey, 744 F. Supp. 1323, 1349 (E.D. Pa. 1990), aff'd in part, rev'd in part, 947 F.2d 682 (3d Cir. 1991), aff'd in part, rev'd in part, 112 S. Ct. 2791 (1992) (noting that the waiting period and informed consent provisions of the 1989 Act were very similar to those in the 1982 Act, which had been invalidated).

282. See Pa. Legis. Journal-House 19-25 (daily ed. Oct. 24, 1989). This understanding of Webster was shared by the Third Circuit Court of Appeals, which applied the undue burden standard as enunciated by Justice O'Connor in her earlier opinions to the new Pennsylvania regulations. See Planned Parenthood v. Casey, 947 F.2d 682, 691-98 (1991), aff'd in part, rev'd in part, 112 S. Ct. 2791 (1992).

283. See Pa. Legis. Journal-House 11-19 (daily ed. Oct. 24, 1989). 
mine whether in practice they create a substantial obstacle to abortion access. The first stage of such a calculation is to examine each provision separately and establish whether the actual and symbolic effects of the provision create a substantial obstacle.

The factual record compiled by the district court indicates several ways in which the Pennsylvania requirements might create obstacles to abortion access. The state-mandated lecture requirement would leave physicians with less time to perform abortions, so that clinics would need to either expand physicians' schedules or hire additional physicians to provide the same level of abortion services. ${ }^{284}$ Both of these alternatives would lead to an increase in operating costs which would be passed on to patients. ${ }^{285}$ In addition, the severe shortage of abortion providers nationwide suggests that the second alternative might not be available. ${ }^{286} \mathrm{~A}$ decline in the level of abortion services leads to longer delays for women seeking abortions. In some cases, for example where women are pregnant with anomalous fetuses, the information may have a deleterious psychological effect and cause "undesirable and unnecessary anxiety, anguish and fear." 287 The physician must provide the information, even if she believes it will have a negative psychological effect, unless she can prove this negative psychological impact will constitute a severely adverse effect on the life or health of the woman or unless a medical emergency exists. ${ }^{288}$

State-mandated lectures, particularly combined with a mandatory waiting period, may also exert coercive psychological pressure. The lecture may convey the symbolic message that the state does not trust women to make an informed and deliberative decision, ${ }^{289}$ and thereby lead women to doubt their ability to determine their best interests. The potential for psychological pressure is magnified by the fact that the lecture is, at least in part, conducted by a physician prior to an invasive medical procedure. In such a context, a woman may feel compelled to ask for all the materials offered to her, may pay particular heed to what her doctor tells her, and may be especially vulnerable because of anxiety about the upcoming procedure.

There was substantial evidence in the record that the mandatory twenty-four hour waiting period will create an undue burden. The wait-

284. See Casey, 744 F. Supp. at 1353, 1380.

285. See id. The record did not indicate how large this increase would be.

286. See Stanley K. Henshaw \& Jennifer Van Vort, Abortion Services in the United States, 1991 and 1992, 26 Fam. Plan. Persp. 100, 103 (1994) (84 percent of all U.S. counties, and 94 percent of nonmetropolitan counties, had no identified abortion provider in 1992); Clinic Works to Find Doctor for Abortions, Philadelphia Inquirer, Nov. 27, 1992, at B6 (reporting the difficulties a Pennsylvania clinic faced in finding physicians willing to perform abortion services).

287. Casey, 744 F. Supp. at 1354.

288. See $18 \mathrm{~Pa}$. Cons. Stat. Ann. § 3205 (Supp. 1994).

289. See Planned Parenthood v. Casey, 112 S. Ct. 2791, 2841-42 (1992) (Stevens, J., concurring in part and dissenting in part). 
ing period forces women who travel to reach an abortion provider to double their travel time and expense, or pay the additional cost of staying overnight near the provider. The district court found that forty-two percent of the women who received abortions in Pennsylvania in 1988 had to travel at least one hour, and sometimes more than three hours, to reach the nearest abortion provider. Other potential costs were lost wages from having to take an additional day off work or payment for additional childcare. Moreover, these costs will be particularly burdensome for poor women. ${ }^{290}$ In some instances, it may be possible to shift the increased costs of regulations onto wealthier women or women who have insurance coverage for abortion. But in this case such shifting is not possible; poor women who must travel to reach an abortion provider cannot avoid paying increased costs. The district court further found that the resulting delays would in fact extend from forty-eight hours to two weeks rather than the mandated twenty-four hours, because of the schedules of abortion clinics. Delays also increase costs indirectly, by pushing some patients into the second trimester. ${ }^{291}$ The health risks of abortion also increase with delays, again particularly if delays result in second trimester abortions. Delays also can cause psychological harm, and the need to make two visits to abortion providers increases the psychological pressure from harassment. ${ }^{292}$

The Pennsylvania regulations mandate that abortion providers file detailed reports that list information on the patient, the clinic where the abortion was performed, and the names of the physician performing the abortion and the referring physician. These records will be made public if the provider has received public funds within the last year. ${ }^{293}$ The district court held that the fear of physician harassment and of potential attacks on their clinics would lead abortion providers not to accept any public funds. ${ }^{294}$ Public funds are available for women on public assistance if the pregnancy endangers their lives or results from reported rape or incest. ${ }^{295}$ All of the clinics challenging the regulations accepted such payments as payment in full. ${ }^{296}$ Thus the requirement that these reports be made public would substantially increase the costs of an abortion for women who qualify for abortion funding, and on this ground would create an undue burden. The requirement that the names of referring physicians must be reported is also burdensome. Evidence in the record

290. See Casey, 744 F. Supp. at 1351-52.

291. Delays may also impact the hardest on poor women, because many poor women are forced to delay scheduling their abortions initially because of their financing difficulties. See NARAL, Promoting Reproductive Choices, supra note 164, at 30.

292. See Casey, 744 F. Supp. at 1367-68.

293. See 18 Pa. Cons. Stat. § 3214 (Supp. 1994).

294. See Casey, 744 F. Supp. at 1366-68.

295. See NARAL, Who Decides?, supra note 216 , at 106.

296. See Casey, 744 F. Supp. at 1334-41. 
showed that many physicians would refuse to refer patients for abortions if their names were listed, for fear of anti-abortion harassment. ${ }^{297}$

The husband notification requirement was the only requirement struck down by the Supreme Court in Casey. As the Casey opinion noted, considerable evidence was presented on the effect that notification requirements have on abused women, such as the fact that notification of pregnancy is connected to increased abuse. Marital problems, often involving violence, are the primary reason women give for not notifying their husbands when the husband is the father. Exceptions to the notification requirement were narrow; for instance, the pregnancy from sexual assault exception could only be used if the woman had reported the assault within ninety days. The requirement would also be burdensome for women who did not wish to inform their husbands for other reasons, such as that the husband was not the father or that the husband would try to pressure her into having the baby or retaliate against her. ${ }^{298}$

In the second stage of the new methodology, the separate provisions are reviewed to ensure that they are rational. The type of rationality review applied is the rationality-with-bite approach, which requires that the regulations actually serve to foster their stated aim. ${ }^{299}$ According to the undue burden standard, rationality review need not be applied to provisions deemed to create substantial obstacles; rather, these provisions are automatically invalidated. Nonetheless, applying rationality review may still be useful since it can serve to buttress the conclusion that regulations should be invalidated.

There is a strong argument for concluding that the physician counselling requirement and some of the reporting requirements are not rational measures. The factual record indicates that all of the clinics challenging the regulations currently require counselling to ensure that women are comfortable with their decision to have an abortion. These counselling sessions are conducted by trained counsellors who often hold advanced degrees, and material on alternatives to abortion is usually available. ${ }^{300}$ The district court found that these counsellors would be more understanding than physicians and would have more time to spend with patients. ${ }^{301}$ Both the American College of Obstetricians and Gynecologists and the American Public Health Association officially favor the use of trained counsellors to provide abortion counselling. ${ }^{302}$ Although the Casey opinion held that the reporting requirement served the public interest in preserving health, there is no evidence in the record of a health benefit from reporting the name of the referring physician. The Federal Standard Report, which is a model for abortion reporting, does

297. See id. at 1370-71.

298. See id. at 2826-30.

299. See supra notes $187-191$ and accompanying text.

300. See Casey, 744 F. Supp. at 1335-42.

301. See id. at 1353.

302. See id. at 1352. 
not require the name of the referring physician. ${ }^{303}$ Since these requirements yield no actual benefits, they would fail to pass rationality review. 304

Similar claims could be made about much of the information that must be supplied and the waiting period requirement, but with less success. Given the evidence in the record that information on fetal development may cause psychological harm, the Casey opinion's claim that the mandated lecture and materials will serve the goal of psychological wellbeing is dubious. ${ }^{305}$ It is also apparent that some of the mandated information could be misleading if not presented realistically, and thus actually could impede informed consent. For example, many women may not be eligible for medical assistance benefits for childbirth. The record contains evidence that most women give careful thought to the decision to have an abortion and have already decided that an abortion is in their best interests prior to scheduling an appointment. Few women display ambivalence about this decision in counselling. ${ }^{306}$ Particularly for those women who refuse the materials made available, the waiting period seems little designed to advance their deliberations. But these measures may also convince some women to forego an abortion and therefore cannot be found to be irrational if the state's broader purpose is to foster childbirth.

Lastly, the husband notification requirement also fails rationality review. The Casey opinion denied that husband notification requirements for abortion serve a legitimate interest, instead finding that these requirements are based on sexist ideas about a wife's dependence on her husband. According to the Court, "parental notification or consent requirements ... are based on the quite reasonable assumption that minors will benefit from consultation with their parents ... . We cannot adopt a parallel assumption about adult women." 307

In the third stage of the new methodology the cumulative burden of the separate provisions is assessed. Again, this stage need not be reached if all of the provisions considered separately create undue burdens or fail rationality review, but an examination of the regulation's cumulative effects will often add support to such conclusions. Each provision increases the costs of abortion, and their combined costs are even more substantial. This cumulative cost is exacerbated by the fact that Pennsylvania does not provide funding for abortions in general, does not cover most abortions for state employees, does not allow abortions to be performed at public

303. See id. at 1370.

304. See Planned Parenthood v. Casey, 112 S. Ct. 2791, 2851-52 (1992) (Blackmun, $\mathrm{J}$., concurring in part and dissenting in part).

305. See id. at 2823 (joint opinion) (stating that informing women of the effect of an abortion on a fetus may reduce the risk of post-abortion psychological trauma).

306. See Casey, 744 F. Supp. at 1351, 1354.

307. Casey, 112 S. Ct. at 2830 . The Court did not apply rationality review to this requirement because it found that the provision created an undue burden. 
facilities and forbids post-viability abortions except in extreme circumstances. ${ }^{308}$ The undue burden that these increased costs would create is demonstrated by examining the financial barriers on abortion access even before the new regulations. The record demonstrated that the vast majority of the clinics challenging the regulations reduced the cost of abortions for women who usually receive medical assistance from the state but would not be eligible for abortion coverage. ${ }^{309}$ Even with such reductions, poor women paid at least $\$ 170$ and potentially as much $\$ 650$ for an abortion, depending on the clinic and the stage of the pregnancy. ${ }^{310}$ The national poverty threshold was $\$ 11,186$ for a single woman and two children in 1993, so that before the regulations were enacted an abortion might represent between twenty and seventy-five percent of the monthly income of poor women. ${ }^{311}$ Hence, seemingly small increases in the costs of abortions might push abortion services out of the reach of many poor women. ${ }^{312}$

The fourth stage of the new methodology, based on the logic of the surrogacy test, singles out restrictions on minors for special scrutiny. This aspect of the proposed methodology represents perhaps the greatest difference from the approach the Court took in Casey. The joint opinion allotted the parental consent requirement only three paragraphs' discussion. ${ }^{313}$ But the requirement that parent consent must be "informed" is problematic. This requirement does not increase familial communication and support when applied to parents who have already given their consent. The district court found that the "informed consent" requirement will require a parent to come to the clinic with the minor for the mandated lecture, and that this may lead to delay because of a parent's schedule. The district court also found that delays are particularly burdensome for minors, because minors often become aware of their pregnancies later than adult women. The health risk of second trimester

308. See NARAL, Who Decides?, supra note 216, at 105-06.

309. See Casey; 744 F. Supp. at 1334-42.

310. See id.

311. See U.S. Bureau of the Census, U.S. Dep't of Commerce, Current Population Reports: Poverty in the United States: 1992, at vii (1993). The poverty thresholds are calculated according to household size; thus $\$ 11,186$ represents the threshold for a family of three, $\$ 14,335$ the threshold for a family of four and $\$ 7,143$ the threshold for a single person. See also Alan Guttmacher Institute, Issues in Brief: August 1993, at 2 (Aug. 1993) (Table) (the average cost of an abortion is 59 percent of the maximum monthly AFDC payment in Pennsylvania, which is $\$ 421$ for a family of three).

312. According to the U.S. Bureau of the Census, 12 percent of women in Pennsylvania have incomes below the poverty line in 1993. For women aged 12 to $17,14.2$ percent have incomes below the poverty line; for women aged 18 to $64,11.2$ percent have incomes below the poverty line.

313. See Planned Parenthood v. Casey, 112 S. Ct. 2791, 2832 (1992) (joint opinion); see also The Supreme Court, 1991 Term, supra note 58, at 206-10 (criticizing the Court's application of the undue burden standard to Pennsylvania's informed consent requirement). Another example of the limited review of minors' restrictions is Barnes v. Mississippi, 992 F.2d 1335, 1337 (5th Cir. 1993). 
abortions is much greater for minors, and minors react more negatively to delays. ${ }^{314}$ Because of their age, minors may also be more susceptible to coercive psychological pressure.

This examination of the effect of the Pennsylvania regulations using the new methodology suggests that many of the regulations create an undue burden. Because of their effect on costs, the waiting period and physician counselling requirements may represent substantial obstacles on their own. The requirement that parental consent must be "informed" should also be invalidated as creating an undue burden. The physician counselling requirement and referring physician reporting requirements should be struck down as irrational. The burdens individually imposed by other measures, such as the provision of information on fetal development, are less clear; however, there is a strong basis for concluding that the regulation as a whole creates an undue burden. Some regulations, such as the requirement that abortion providers provide information on the risks of abortion and carrying a pregnancy to term and basic reporting requirements should be sustained if severable from the other provisions.

It is important to realize that these conclusions do not merely represent a philosophical disagreement with the Court's assessment of the effects of the regulations or the proper scope for state restrictions on abortion. Instead, these conclusions result from employing a conceptually similar but more rigorous undue burden methodology. Several of the effects considered here were not mentioned by the Court, for instance the negative psychological impact of fetal depictions and the refusal of physicians to make abortion referrals if the fact that they do so becomes public. Other effects, most centrally the impact of increased costs, are weighed differently because the new methodology stipulates that costs should be assessed from the perspective of poor women. Lastly, the joint opinion authors performed no cumulative assessment of burdens and only a minimal rationality review.

\section{Narrow Tailoring and the Abortion Undue Burden Standard}

The new undue burden methodology accords with the structure of the undue burden standard as enunciated in Casey, although in practice the new methodology leads to very different results. It is also worthwhile to consider the effects of altering the structure of the undue burden standard to address the lack of protection against unnecessary but not undue burdens. The comparison of the undue burden standard and the three other constitutional models demonstrated that, lacking balancing or an examination of alternative regulations, the undue burden standard is unique in its failure to protect against burdens that are unnecessary to achieve the government's purpose but do not rise to the level of undue burdens. The lack of protection is reinforced by the fact that the state 
can express its preference for childbirth, since this ability makes it difficult to invalidate regulations on purpose or rationality review.

The Casey joint opinion clearly states that all regulations not found to impose an undue burden will only be subjected to rationality review, where there is no comparison of alternatives. Although the rationalitywith-bite approach examines the actual effects of a regulation, it does not look outside of the confines of the enacted regulation. Thus any attempt to include a comparison of alternatives in order to address the lack of protection against unnecessary but not undue burdens will not accord with the Casey undue burden framework. Nevertheless, it is useful to see what effect a weak narrow tailoring requirement, such as that found in content-neutral, traditional forum analysis, would have on the review of abortion regulations. This version of narrow tailoring only requires an inquiry into whether equally effective, less burdensome alternatives exist; it does not allow the Court to strike down regulations that it believes on balance are too burdensome or otherwise unjustified.

The effects of a narrow tailoring requirement can again best be seen by applying this requirement to some of the provisions at issue in Casey. Any measure that fails rationality review also would fail the narrow tailoring requirement, but the converse is not true. As discussed above, there was strong evidence in Casey that the mandated anti-abortion lecture imposed unnecessary burdens. However, the measure would likely satisfy rationality review because it allowed the state to express a preference for childbirth. But under the narrow tailoring requirement the mandated lecture would likely be struck down because of the availability of equally effective alternatives that are less burdensome. For example, a state could make materials expressing this preference generally available, allow a woman to choose not to hear the state-mandated lecture or provide wide discretion to counselors not to provide the lecture if they believe it will be harmful. The usefulness of an examination of alternatives is also evident in regard to the waiting period requirement. It is important to recognize that the waiting period requirement would survive rationalitywith-bite review, even though this requirement would likely be struck down as imposing a substantial obstacle to abortion access under the new methodology. The fact that equally effective and less burdensome measures are available provides additional support for such invalidation. One such alternative is a waiting period requirement that commences with the patient's initial telephone contact with the abortion provider. The Eighth Circuit recently upheld a waiting period provision in North Dakota, relying on an opinion by the state Attorney General which claimed the provision was satisfied by telephone counselling. ${ }^{315}$

315. See Fargo Women's Health Org. v. Schafer, 18 F.3d 526, 530-31 (8th Cir. 1994). However, this type of counselling requirement may be more likely to be deemed irrational since the absence of face-to-face contact might lessen the quality of the counselling. 
Although the narrow tailoring requirement is not consistent with the undue burden framework enunciated in Casey, it would not radically alter the balance the joint opinion sought to strike between the interests of the woman and the interests of the state. It would serve mainly to reinforce the rationality review already contained within the undue burden standard.

\section{CONCLUSION}

The undue burden standard enunciated by the Supreme Court in Casey was based on the principle that the Constitution protects the right to choose abortion. It is necessary to have a methodology for applying the undue burden standard to ensure that this protection exists not just in theory but also in fact. This Note has sought to develop such a methodology by drawing on the techniques used in other constitutional models. The combined use of the per se rule against facially undue burdens and a general investigation of purpose offers a means of giving subs_ance to the purpose prong of the undue burden standard. Enhanced rationality review, as well as an examination of cumulative and symbolic effects and a focus on the impact of regulations on poor women, helps to structure the inquiry under the effects prong. The surrogacy test indicates when careful scrutiny of restrictions on minors is particularly necessary.

While these methods provide greater guidance, they are not sufficient to protect women against unnecessary but not undue burdens. For such protection to exist, an examination of alternatives and a narrow tailoring requirement must be added to the abortion undue burden standard. Without such a requirement the protection of abortion rights will be substantially less than the protection offered to other rights under comparable constitutional standards. 
